\title{
First discovery of Mississippian trace fossils in the Świebodzice Unit from the Witoszów region (SW Poland)
}

\author{
Jolanta MUSZER ${ }^{1, *}$ \\ 1 University of Wrocław, Institute of Geological Sciences, Cybulskiego 30, 50-205 Wrocław, Poland
}

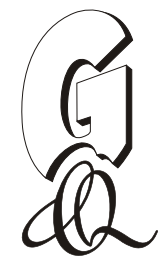

Muszer, J., 2020. First discovery of Mississippian trace fossils in the Świebodzice Unit from the Witoszów region (SW Poland). Geological Quarterly, 64 (4): 838-860, doi: 10.7306/gq.1558

Associate Editor: Michał Zatoń

Abundant and moderately diverse trace fossil assemblage have been discovered for the first time in mudstones of the Pogorzała Formation from the Witoszów region, SW Poland. Fifteen ichnospecies including fourteen ichnogenera are described. The ichnofauna is dominated by Dictyodora liebeana and contains numerous Palaeophycus tubularis, rarer Archaeonassa fossulata, Archaeonassa isp., Chondrites cf. intricatus, Curvolithus simplex, Diplopodichnus biformis, Lockeia isp., ? Lophoctenium isp., Nereites isp., Phycosiphon isp., Protovirgularia isp., ? Psammichnites isp., Taenidium isp. and one ichnospecies of fish swimming trails, Undichna cf. britannica. Some other structures (wave ripples influenced by microbial mats and zigzag structures) also occur. The trace fossil assemblages differ in various exposures, but three of them are similar and display the Dictyodora liebeana ichnoassemblage. It is represented mostly by the ethological categories fodinichnia and repichnia, with fewer pascichnia, domichnia and cubichnia. This new data from the Świebodzice Unit sheds light on the palaeontology, age and palaeoenvironment of the Pogorzała Formation. The occurrence of $D$. liebeana and $U$. cf. britannica indicates the Mississippian age of most mudstones studied, formerly considered Upper Devonian. The trace fossil assemblage belongs to the non-standard Nereites ichnofacies, without graphoglyptids. The lithological features of mudstones, trace fossil assemblage and poverty of macrofauna, testify to their deposition in a deeper sedimentation zone below storm wave base, most likely in dysaerobic, pro-delta conditions. This study suggests that rocks containing $D$. liebeana may form a correlative horizon in the Świebodzice Unit.

Key words: Świebodzice Unit, Pogorzała Formation, Mississippian, trace fossils, fish trails, ichnofacies.

\section{INTRODUCTION}

The Świebodzice Unit (or Świebodzice Depression) is a small, rhomboidal, fault-bounded geological unit (Fig. 1) in the central Sudetes, which was de facto defined in the 1950s (Teisseyre, 1956b). Before the Second World War, German researchers (e.g., Berg et al., 1910; Cramer et al., 1921) recognised the same lithological units in the area as in the neighbouring Intra-Sudetic Synclinorium (named after Żelaźniewicz et al., 2011). Porębski (1987, 1990) and Wojewoda $(2014,2016 a, b)$ explained the rhomboidal shape of the Świebodzice Unit and referred it to a pull-apart basin. The Świebodzice Unit comprises 3300-4500 m of sedimentary rocks, predominantly conglomerates, the so-called Świebodzice succession (Porębski, 1981). This succession generally is divided into two parts, a heterolithic succession and coarse-grained conglomerates, with their age determined variously since the 19th century.

*E-mail: jolanta.muszer@uwr.edu.pl

Received: March 9, 2020; accepted: August 4, 2020; first published online: September 30, 2020
The detailed history of geological investigations in the Świebodzice Unit was summarized by Gunia (1968). Most maps of German authors (e.g., Berg et al., 1910) considered the heterolithic deposits to be older than the coarse-grained conglomerates. This opinion was accepted by later researchers (e.g., Teisseyre, 1948, 1952, 1968b; Nemec et al., 1980; Porębski, 1981). But there was an opposing opinion, of Cramer et al. (1924), suggesting that the gneiss conglomerates (presently the Książ Formation) were older than the heterolithic rocks (currently the Pogorzała Formation).

Biostratigraphic documentation of this geological unit has been based on macrofossils, which have been found since the 19th century (see Gunia, 1968 and references therein). They represent Devonian (mainly in limestones) and Carboniferous taxa of fauna and flora. The macrofossils are generally poorly preserved and most of them are long-ranging taxa. They are also unevenly distributed and some Devonian fossils are reworked (they occur in pebbles; Gunia, 1968). For these reasons, interpretation of the stratigraphy is complicated. Extensive stratigraphic studies of the rocks of the Swiebodzice Unit, based on marine macrofauna, were undertaken by Gunia (1968). This author, like others before him, assumed that all the fossils found occur "in situ". Based on relatively rare index fossils, Gunia (1968) concluded that both parts of the unit 


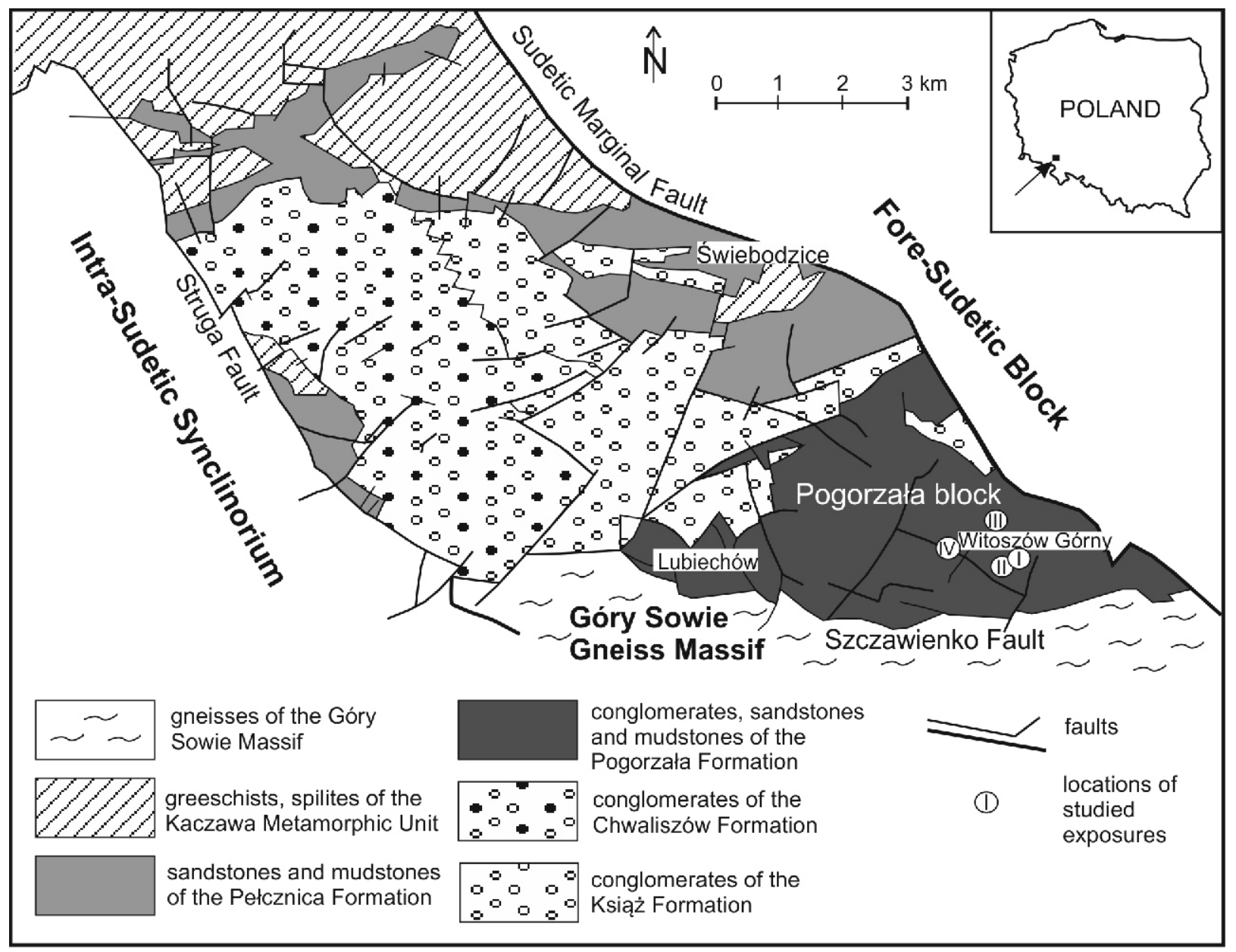

Fig. 1. Geological map of the Świebodzice Unit (based on Kaczorowski and Wojewoda, 2011) with location of the exposures studied in the Witoszów region

(heterolithic and coarse-grained conglomerates) are stratigraphically equivalent and were deposited from the late Frasnian to the Tournaisian. Only one Carboniferous taxon Lepidodendron sp. from the Książ conglomerates found by Zimmerman (1936) was taken into account by Gunia (1968). This author rejected all other Carboniferous dates (see Pluta and Górecka-Nowak, 2018). Significant, but often overlooked results were provided by Krawczyńska-Grocholska (1973), which documented miospores of Visean-Namurian age in the Chwaliszów region. There were no subsequent stratigraphic investigations for nearly a half century. Recently, Halamski (2013) published new palaeontological and biostratigraphical studies of Devonian brachiopods from limestones of the Świebodzice Unit.

The view of Porębski $(1981,1990)$ has been the most frequently cited and commonly accepted. This author, based on sedimentological studies and the general stratigraphical scheme of Gunia (1968), proposed a formal lithostratigraphic division of the Świebodzice succession. According to Porebski (1981, 1990), the lower, heterolithic, part of the succession (1200-1500 m in thickness; the Pogorzała Formation and the Pelcznica Formation), is represented by polymictic conglomerates interbedded with thick fossiliferous mudstones with sandstones and rare organogenic limestone lenses. The age of this part was regarded as Upper Devonian (upper Frasnian-Famennian). In contrast the upper part of the Świebodzice succession, in the opinion of Porębski (1981, $1990)$, is represented by thick-bedded and coarse-grained conglomerates with sandstones of the Książ Formation (2000 m in thickness; with the presence of gneiss pebbles) and the Chwaliszów Formation (3000 m in thickness; polymictic conglomerates). These deposits were referred to the lower Tournaisian and probably in part to the Upper Devonian (see Gunia, 1968; Porębski, 1981). The Świebodzice succession is considered synorogenic and reflects mostly gravity-flow sedimentation in a marine slope-type fan-delta complex of a rapidly subsiding basin (Nemec et al., 1980; Porębski, 1981, 1987, 1990).

Recently, Wojewoda $(2014,2016 a$, b) presented a different developmental model of the Swiebodzice Unit on the basis of cartographic and structural/sedimentological investigations using LIDAR methods. According to this, the conglomerates of the Książ and Chwaliszów formations, found in the central part of this unit, are older than the heterolithic Pogorzała and Pełcznica formations from its marginal parts and represent the Tournaisian-Namurian interval. In contrast the heterolithic formations are of the Namurian-Westphalian age and within them this author distinguished turbidites, hemipelagic and pelagic facies including olistoliths and slumps of older rocks (e.g., upper Devonian limestones) occurring near basin edges. This model explains well the occurrence of age-different taxa (Devonian and Carboniferous) in the heterolithic formations. Therefore, the age of the Pogorzała Formation cannot be correctly determined on the basis of redeposited Devonian body fossils.

The latest results of miospore studies of the Pogorzała Formation (Pluta and Górecka-Nowak, 2018) are important to discussion of the stratigraphy of this unit. These authors docu- 
mented the Upper Visean-Serpukhovian age for rocks from the Pogorzała Formation in the Witoszów and Lubiechów regions, formerly interpreted as the Upper Devonian (Gunia, 1968). The presence of Asturian (Westphalian) miospores in a few samples of these rocks, they interpreted as reflecting redeposition of stratigraphic leakage type. These new data support the model of Wojewoda (2014, 2016a, b). Pluta and Górecka-Nowak (2018) also conducted a detailed discussion of stratigraphic problems. They cited the pre-Second World War finds of Carboniferous macrofauna and macroflora from the Pogorzała Formation, which were not taken into account by Gunia (1968). As these authors emphasized, present-day understanding of the geological setting and stratigraphy remains unsatisfactory, indicating that the geological history of the unit is more complicated than previously thought. According to them, the age of the rocks of the Świebodzice Unit has fundamental importance for the interpretation of geological history of the Central Sudetes.

Until now, no trace fossils have been reported from the Świebodzice Unit. Initially, individual undetermined trace fossils, described formerly by Prof. T. Gunia as sedimentary structures, were noticed by the author in 2019, while organizing the Gunia collection from Witoszów. Then, fieldwork revealed many more finds and the preliminary results of these studies were reported by Muszer (2019). This contribution provides the first comprehensive ichnological study of the Świebodzice Unit, focusing on mudstones of the Pogorzała Formation. Based on ichnological investigations, some important stratigraphic and palaeoenvironmental conclusions can be drawn. Trace fossils are important, commonly being used to reconstruct palaeoenvironments because they represent the in situ record of biogenic activity and cannot be easily reworked (Minter et al., 2016).

Mississippian trace fossils from the central part of the Polish Sudetes are best known from the Upper Visean of the Bardo Unit (Muszer and Haydukiewicz, 2009, 2010; Muszer and Uglik, 2013). For many years they were mentioned, without description, from the Intra-Sudetic Synclinorium (Żakowa, 1958, 1960; Teisseyre, 1968a; Nemec et al., 1982; Mastalerz, 1987, 1995). Recently, two reports of trace fossils from the Szczawno Formation of the Intra-Sudetic Basin were provided by Muszer $(2013,2020)$ and further studies are in preparation.

\section{GEOLOGICAL SETTING}

The research area is located in the southeastern part of the Swiebodzice Unit, in the "synclinal block" of Pogorzała, which is fault-bounded (Fig. 1; see Teisseyre, 1956a; Porębski, 1981). This block extends across the Pogorzała, Witoszów, Mokrzeszów and Lubiechów regions (Teisseyre, 1956a). The Pogorzała block is built of conglomerates, greywackes and shales with rare, small "bodies" of organogenic limestone (considered either lenses or olistoliths according to various authors, cf. Porębski, 1981 and Wojewoda, 2016a), which belong to the Pogorzała Formation (Porębski, 1981). The total thickness of this succession was estimated at 1200-1500 m (Teisseyre, 1956a).

In the Witoszów Górny area there are a number exposures of the Pogorzała Formation represented by mudstones with intercalations of sandstone (greywacke) and conglomerate. The mudstones are grey to dark and green grey, commonly thinly laminated (up to a few $\mathrm{mm}$ ), with rare pyrite concretions. Alternating light and dark laminae occur. Marine fossils have been sporadically noted in these mudstones and less frequently in

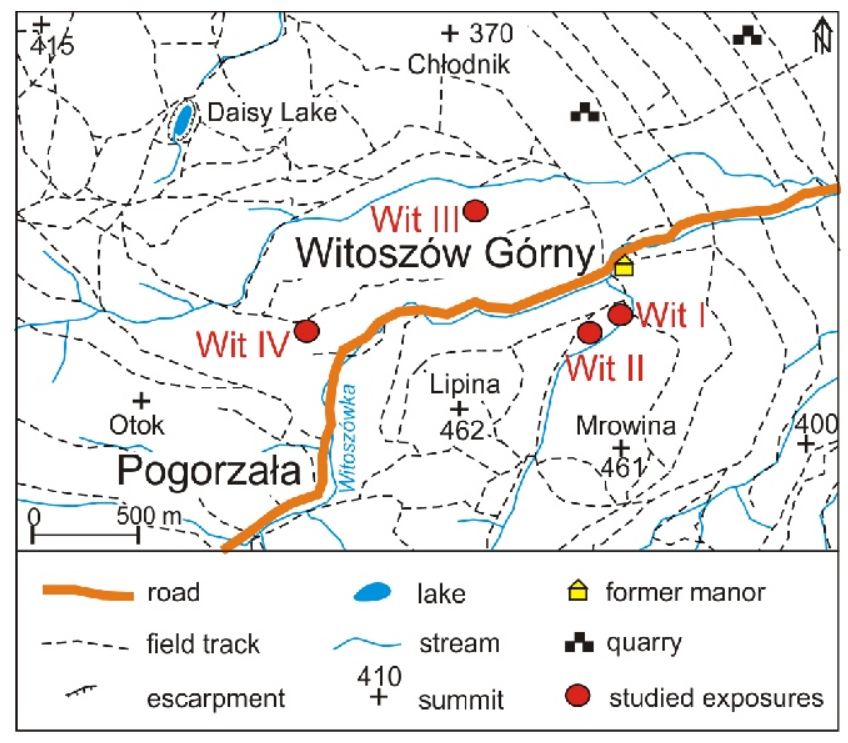

Fig. 2. Topographic sketch of the Witoszów Górny region with location of the exposures studied

the greywackes. Plant fossils (mainly debris) are slightly more common than macrofaunal fossils.

In these rocks, some Carboniferous taxa were noted in 19th and 20th centuries, especially from a "roofing slate" quarry (e.g., the bivalves Posidonia becheri, Edmondia, Protoschizodus by Dames, 1868 and Bederke, 1924; the land plants Mesocalamites roemeri, Calamites tenuissimus and Sigilaria minutissima by Cramer et al., 1924). However, most studies have suggested that the Pogorzała Formation is Devonian, because of numerous marine macrofaunal remains, found in limestone "bodies" occurring in mudstones in neighbouring regions (Zobell and Carnall, 1831; Dames, 1868; Gürich, 1909; Różkowska, 1962). Pawlik (1939) considered the mudstones at Witoszów as younger than the calcareous deposits and include them to the "stufe Hemberg" (Famennian, Prolobites and Prionoceras Zones). According to Gunia (1968), these mudstones represent the Upper Devonian (Famennian), but their palaeontological documentation is poor (a few bivalve, brachiopod and cephalopod taxa). Porębski (1981) included the Pogorzała Formation in the Upper Devonian (upper Frasnian-Fammenian). According to Wojewoda (2014, 2016a, b) the Devonian limestone fragments with body fossils are redeposited. The latest palynostratigraphic data (Pluta and Górecka-Nowak, 2018) shed new light on the stratigraphy and rejected the upper Devonian age of the Pogorzała Formation in the southern part of the Świebodzice Unit. These authors documented the Upper Visean-Serpukhovian age for the mudstones from Witoszów Górny and Lubiechów regions and considered all older rocks and fossils as redeposited.

Four mudstone exposures in the Pogorzała Formation in the Witoszów Górny area (Wit I, Wit II, Wit III, Wit IV) were studied (Figs. 1 and 2). They are the same as the localities studied by Gunia (1968), but were not analysed by Pluta and GóreckaNowak (2018). All studied exposures are heavily covered with weathered material (Fig. 3).

The exposure Wit I (outcrop no. 30 of Gunia, 1968) is situated $\sim 300 \mathrm{~m} \mathrm{~S}$ of the historic 17th-century manor house (GPS coordinates $50^{\circ} 48^{\prime} 58.8^{\prime \prime} \mathrm{N}$; $\left.16^{\circ} 23^{\prime} 30.1^{\prime \prime} \mathrm{E}\right)$. The exposure is $\sim 10 \mathrm{~m}$ long and $5 \mathrm{~m}$ high (Figs. 2 and $3 \mathrm{~A}$ ). Grey shales with thin (up to $3 \mathrm{~cm}$ ) intercalations of fine-grained sandstone are ex- 

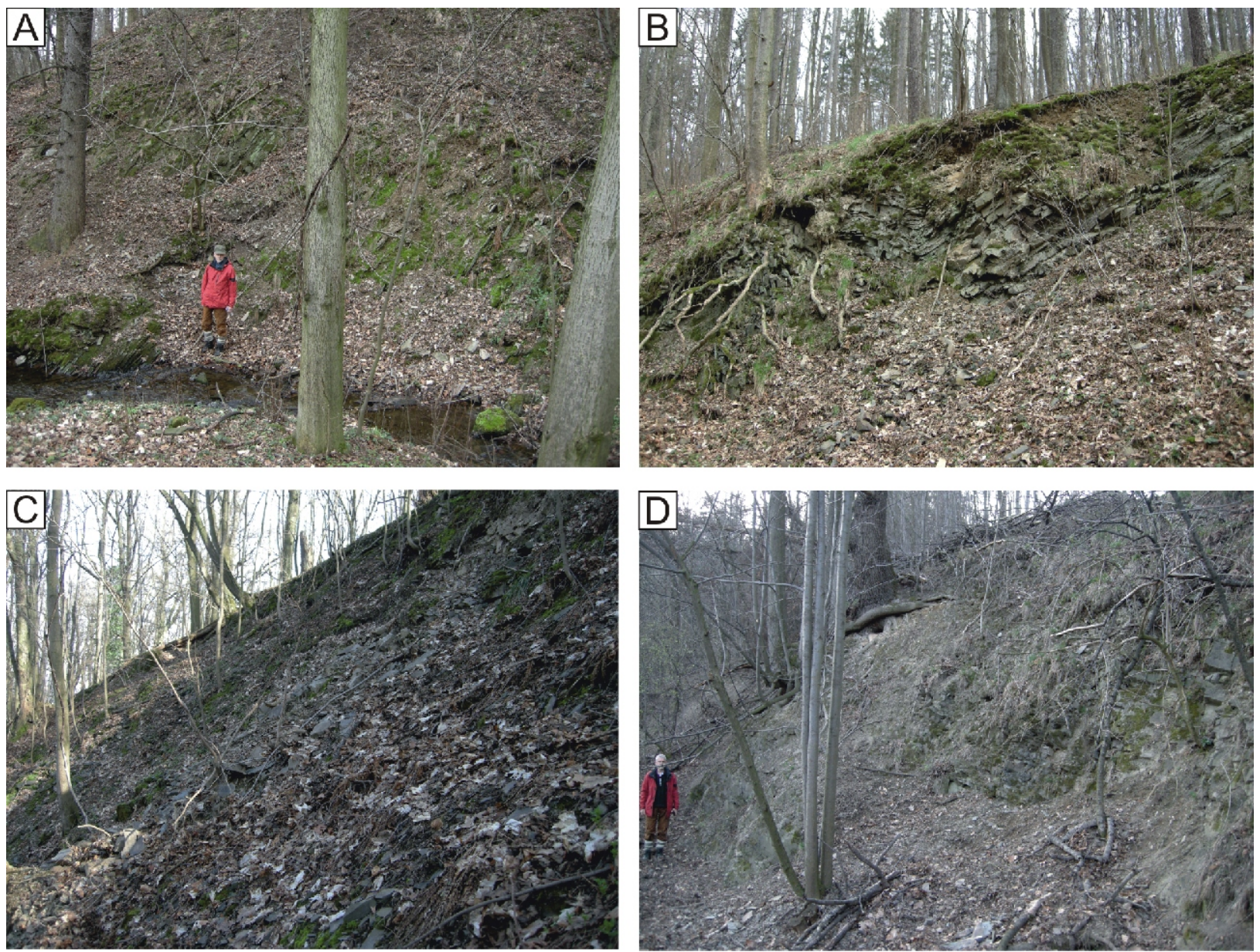

Fig. 3. Photographs of exposures of the Pogorzała Formation in the Witoszów Górny region

A - exposure Wit I; B - exposure Wit II; C - exposure Wit III; D - exposure Wit IV

posed on the slope, on the right bank of the stream. The orientation of the bedding is $3 / 60$. In this exposure numerous trace fossils have been found, besides fragments of land plants (Calamitaceae) and rare undetermined bivalves (Fig. 4D, H). The mudstones are probably overlain by conglomerates with rounded pebbles, and greywackes, which occur in blocks, but the contact with these rocks is not seen.

The exposure Wit II (GPS coordinates 5048'55.6” $\mathrm{N}$; $16^{\circ} 23^{\prime} 24.0^{\prime \prime} \mathrm{E}$ ) is located $\sim 150 \mathrm{~m}$ SW of Wit I, on the northwestern slope of Mrowina Hill (Fig. 2). This locality seems to be the same as outcrop no. 4 of Gunia (1968), but its dimensions are different (now $10 \mathrm{~m}$ long, $7 \mathrm{~m}$ high). On the right bank of the stream, grey, green grey and dark grey shales with thin (up to $1-2 \mathrm{~cm}$ ) intercalations of fine-grained greywacke are exposed The strata dip $\sim 40^{\circ}$ to the north. These rocks are gently folded in the upper part of the exposure (Fig. 3B). Abundant trace fossils, rare plant fragments and undetermined cephalopods (Fig. 4E) occur in these mudstones.

Exposure Wit III (no. 3 of Gunia, 1968) is a large, old and disused quarry, known as the "roofing slate" quarry. It is situated $\sim 750 \mathrm{~m} \mathrm{NW}$ of the former manor (GPS coordinates $50^{\circ} 49^{\prime} 18.3$ 'N; $16^{\circ} 22^{\prime} 53.3^{\prime \prime} \mathrm{E}$ ), on the wooded slope (Fig. 2). The quarry is now strongly overgrown and covered with weathered material (Fig. 3C). It exposes mainly dark grey shales, intercalated with layers (up to $20 \mathrm{~cm}$ ) of greywacke. The bedding orientation is $10 / 40$. Trace fossils occur only in the uppermost part of the quarry. Additionally, only an undetermined fish scale was found (Fig. 4G).

Exposure Wit IV (outcrop no. 11 of Gunia, 1968) is located $150 \mathrm{~m} \mathrm{~N}$ from the western end of the village of Witoszów Górny, on the southern slope of the hill, near the ruins of a former forester's lodge (GPS coordinates $50^{\circ} 48^{\prime} 56.0^{\prime \prime} \mathrm{N}$; $16^{\circ} 22^{\prime} 12.2^{\prime \prime} \mathrm{E}$ ). The exposure is $\sim 15 \mathrm{~m}$ long and $3 \mathrm{~m}$ high (Figs. 2 and 3D). In this profile dark grey, green grey and light grey shales with intercalations of fine-grained greywacke (up to $5 \mathrm{~cm}$ ) are exposed. The rocks are locally gently folded. Measurements of bedding plane are 335/25, 345/30 in the eastern part of the outcrop and $350 / 40$ in its western part. These rocks contain many trace fossils, some plant fossils (Calamitaceae) and rare bivalves (Fig. 4A-C, F, I).

\section{MATERIALS AND METHODS}

Almost all material studied in this paper was found during fieldwork in 2019 (Figs. 2, 4, 5B, D-H and 6-10). Fifty-eight samples were taken from mainly mudstones in the Witoszów region. Some samples were assembled from talus material. Additionally, five samples with trace fossils come from the collection of Gunia (1968; outcrops no. 4, 30 from Witoszów, no. 41 from Lubiechów; Fig. 5A, C). 

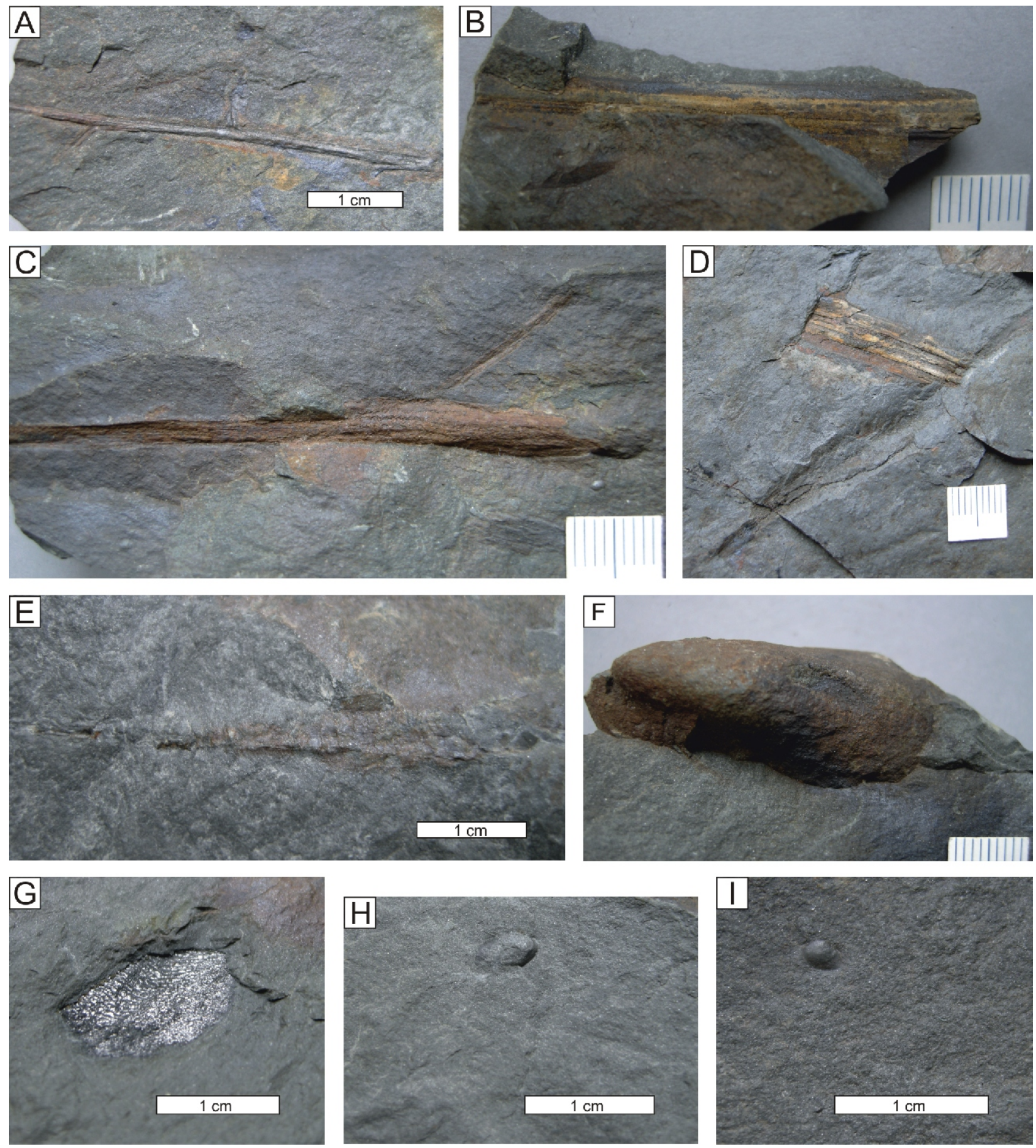

Fig. 4. Associated macrofossils from the Witoszów Górny region

A-D - undetermined Calamitaceae: A - cat. No. Wit IV/3b, B - cat. No. Wit IV/13, C - cat. No. Wit IV/12, D - cat. No. Wit I-1/4a; E - undetermined orthoconch of Cephalopoda, cat. No. Wit II/2a; F - a large bivalve inner mould, probably Modiolus sp. cat. No. Wit IV/10; G - undetermined fish scale, cat. No. Wit III/3; H, I - undetermined very small bivalves: $\mathrm{H}$ - cat. No. Wit I-2/3, I - cat. No. Wit IV/11

Several rock samples were cut and the ichnofabric was observed on polished surfaces using a Nikon SMZ-2T microscope (Fig. 10). Photographs of trace fossils were taken with a Nikon Coolpix P5100 camera. The material collected is housed in the Institute of Geological Sciences of the University of Wrocław with the prefix Wit (catalogue numbers $1-1 / 1-1-2 / 4 b, \mid-z / 1-$ I-Z/3; II/1 - II/12; III/1 - III/3; IV/1 - IV/20), together with five samples from the Gunia collection (samples 4, 30, 41).

\section{DESCRIPTION OF THE TRACE FOSSILS}

INVERTEBRATE TRACE FOSSILS

Ichnogenus Archaeonassa Fenton and Fenton, 1937 Archaeonassa fossulata Fenton and Fenton, 1937 (Fig. 5A) 
Material and occurrence. - Two specimens from the collection of Gunia (1968) (outcrop no. $30=$ Wit I) and one specimen from talus of exposure Wit I.

D e s c r i p t i o n. - Simple, unbranched, straight to meandering, narrow traces up to $92 \mathrm{~mm}$ long and 2.0-5.7 mm wide. Epichnial furrows are parallel to bedding. Margins of the furrow on both sides are bound by irregular and slightly raised levees. One specimen is looping and has a median groove flanked by ridges (Fig. 5A). The loop of this specimen is $40 \mathrm{~mm}$ wide.

Remarks. - The traces are most similar to Archaeonassa fossulata described by Buatois and Mángano (2002: fig. 7A) from the Carboniferous floodplain deposits of Argentina, but a V-shaped cross-section is not clear in the specimens from Witoszów. They are also similar to Archaeonassa cf. fossulata described by Demircan and Uchman (2016: fig. 4A, B) from the prodelta facies of the Paleogene of Turkey, but their external margin is more even.

This ichnogenus was reviewed by Buckman (1994) and redefined by Yochelson and Fedonkin (1997). Archaeonassa generally is interpreted as a grazing trail or pascichnion, produced by crustaceans, annelids or molluscs (e.g., Yochelson and Fedonkin, 1997; Buatois and Mángano, 2002; Mángano et al., 2005; Carmona et al., 2006; Sarkar et al., 2009). Knaust (2007) regarded $A$. fossulata as a gastropod burrow (fodinichnion).

This ichnogenus has been described from lake, shallow marine and delta deposits (Buatois and Mángano, 2002; Knaust, 2007; Sarkar et al., 2009; Mángano et al., 2013). It is a common element of the Cruziana and Mermia ichnofacies (Buatois and Mángano, 2002; Melchor et al., 2012). Archaeonassa is known from the Ediacaran (Häntzschel, 1975; Buckman, 1994 Buatois and Mángano, 2002) to the Recent (Netto et al. 2012a), but mainly from the Paleozoic (e.g., Mángano et al. 2005; Pazos et al., 2007).

Archaeonassa isp.

(Fig. 5B, C)

Material and occurrence. - Nine specimens from two exposures, Wit I (= outcrop 30 of Gunia) and Wit IV.

D e s c ription. - Horizontal, straight to curved, unbranched traces with narrow parallel ridges preserved as negative epirelief. They are semicircular or usually V-shaped in cross-section, occasionally flat. Their length is up to $9.2 \mathrm{~cm}$, width is $1.5-0.4 \mathrm{~mm}$.

$\mathrm{R}$ e $\mathrm{m}$ a r ks. - The material is poorly preserved and incomplete, due to the fragile and fractured host rock. Some specimens show a sudden change of a movement direction (Fig. 5B, C).

Ichnogenus Chondrites Sternberg, 1833

Chondrites cf. intricatus (Brongniart, 1823)

(Figs. 5F and 6A, C)

Material and occurrence. - One incomplete specimen from exposure Wit I; several tunnel cross-sections exposed on the bedding surface (exposure Wit IV).

D e s c ription. - System of thin tunnels branching at sharp angles, which look like roots. The length of the tunnels range from $10-20 \mathrm{~mm}$, and their diameter is $\sim 0.2 \mathrm{~mm}$. Tunnels are filled with darker material, differing from the host rock. They are slightly inclined to the bedding surface. Branching angle is $<45^{\circ}$, which is a characteristic feature of Chondrites intricatus (Brongniart, 1823), but branches are not so straight as in this ichnospecies. The diameter and width of the burrow system resembles this ichnospecies (see Uchman et al., 2012). Cross-sections of the tunnels are visible on the bedding surface (Fig. 6A, C).

R e marks. - Chondrites has been interpreted as a fodinichnion (feeding structure) produced by an unknown infaunal deposit feeder (e.g., Seilacher, 2007). Other authors classified this trace fossil as a chemichnion (e.g., Bromley 1996; Mikuláš, 2006; Rodríguez-Tovar et al., 2010). Recently Baucon et al. (2020) re-evaluated Chondrites and considered it as a fodinichnion (created by vermiform deposit-feeders searching for food), agrichnion (when tracemakers cultivate asymbiotic bivalves and ingest bacteria) and chemichnion (produced by chemosymbiotic bivalves to provide symbionts with chemical agents).

This ichnogenus is one of the most common in Phanerozoic marine deposits (Uchman and Wetzel, 1999) and its stratigraphic range is from the Cambrian (Crimes, 1992) to Holocene (Löwemark et al., 2004). It occurs in a variety of ecological conditions, from nearshore to deep-sea and from highly oxic (Wetzel, 1991) to oxygen-depleted sediments, rich or poor in organic matter (Wetzel and Uchman, 2001; Uchman et al., 2003). However, most workers cite Chondrites from low-energy environments (Seilacher, 2007) and substrates with oxygen-poor pore waters (e.g., Tyszka, 1994).

Ichnogenus Curvolithus Fritsch, 1908

Curvolithus simplex Buatois et al., 1998

(Figs. 5D and 9A)

M a t e ri a I a n d o c c u r r e n c e. - Two fragmentarily preserved specimens from exposures Wit I and Wit II.

D e s c r i p t i o n. - Horizontal, curved, flattened and unbranched trace with trilobate upper surface. The central lobe on the upper surface is smooth and much wider than the outer lobes, which are separated by shallow furrows. The specimens described are 5-6 $\mathrm{mm}$ wide and $15-40 \mathrm{~mm}$ long. They are preserved as positive epireliefs on the bedding surface.

$\mathrm{R}$ e $\mathrm{m}$ arks. - The ichnogenus Curvolithus was revised by Buatois et al. (1998), who distinguished only two ichnospecies, C. multiplex Fritsch and a new species C. simplex. Specimens from the Witoszów region are most similar to C. simplex described by Buatois et al. (1998: figs. 4.2-4.3, 7.1-7.6) and by Krobicki and Uchman (2003: fig. 3). Curvolithus is commonly interpreted as a locomotion trace (repichnion) of endostratal invertebrate carnivores (see Buatois et al., 1998 and references therein). The potential tracemakers are gastropods, wormlike polychaetes, flatworms, oligochaetes, nemerteans and holothurians (e.g., Lockey et al., 1987; Seilacher, 2007; Knaust, 2010).

Curvolithus is a common element of the Cruziana ichnofacies sensu Seilacher (1967). Lockley et al. (1987) defined the Curvolithus ichnofacies, which now is considered to be a subset of the Cruziana ichnofacies (Bromley, 1996; Mcllroy, 2008). This ichnogenus is commonly associated with shallow-marine deposits (Buatois et al., 1998). It also occurs in fan-deltaic to offshore deposits (Webby, 1970; Fürsich and Heinberg, 1983; Heinberg and Birkelund, 1984; Maples and Suttner, 1990). 

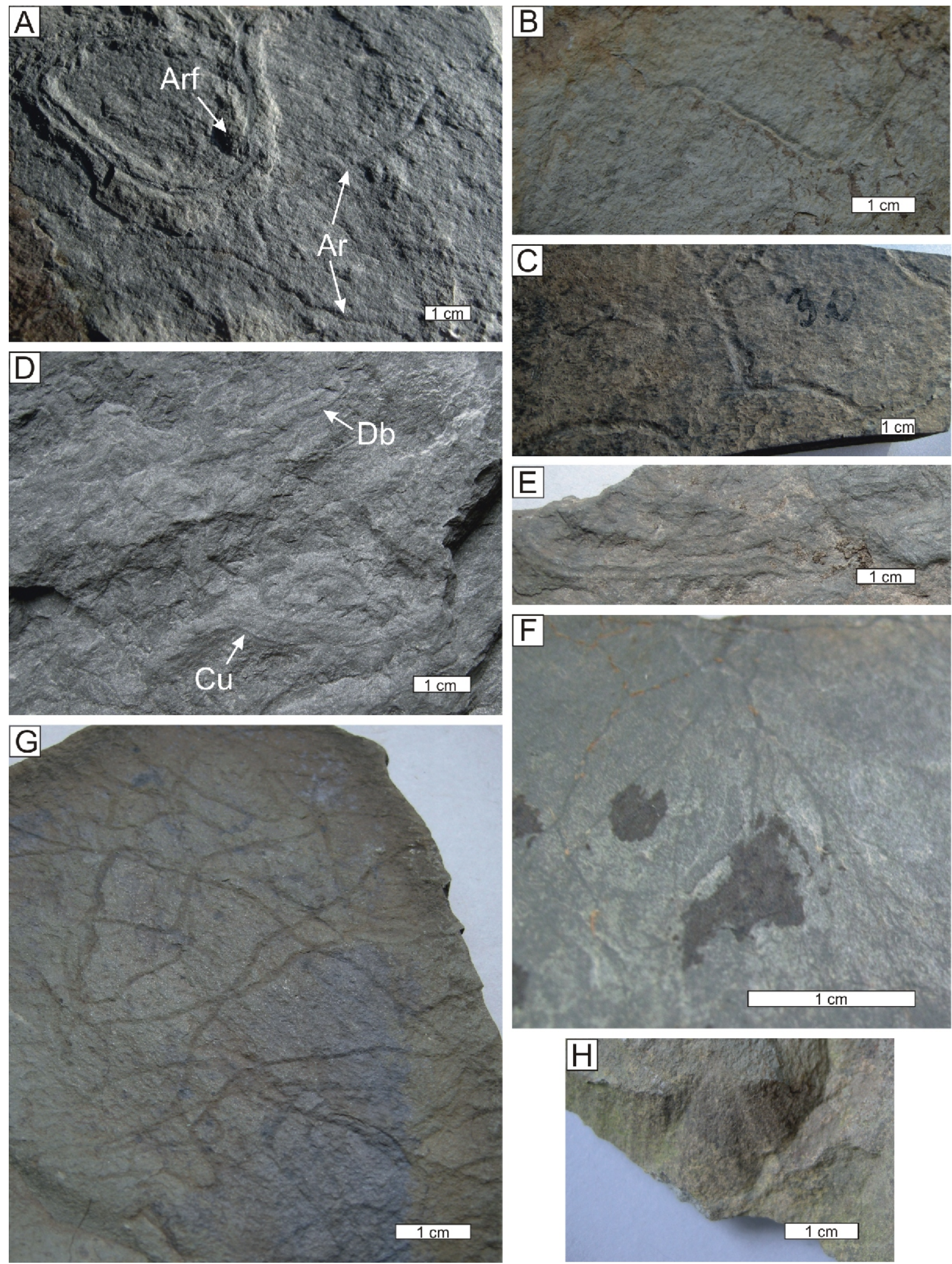

Fig. 5. Trace fossils from the Witoszów region

A - Archaeonassa fossulata (Arf) and Archaeonassa isp. (Ar) preserved as epirelief on the top of the bedding plane, outcrop no. 30 (coll. Gunia, 1968); B, C - Archaeonassa isp. preserved as negative epirelief on the top of the bedding plane: B - cat. No. Wit I-1/1a, C - outcrop no. 30 (coll. Gunia, 1968); D - Diplopodichnus biformis (Db) and Curvolithus simplex (Cu) preserved as positive epirelief, cat. No. Wit II/1a; E - Diplopodichnus biformis preserved as convex hyporelief, cat. No. Wit I-z/1; F - Chondrites cf. intricatus preserved on the surface slightly oblique to the bedding plane, cat. No. Wit I-1/4b; G, H - Dictyodora liebeana: G - horizontal cross-sections of the spreiten structure preserved as epirelief, cat. No. Wit IV/1, $\mathrm{H}$ - visible vertical wall of $D$. liebeana on the surface oblique to the bedding plane, cat. No. Wit I-1/1b 

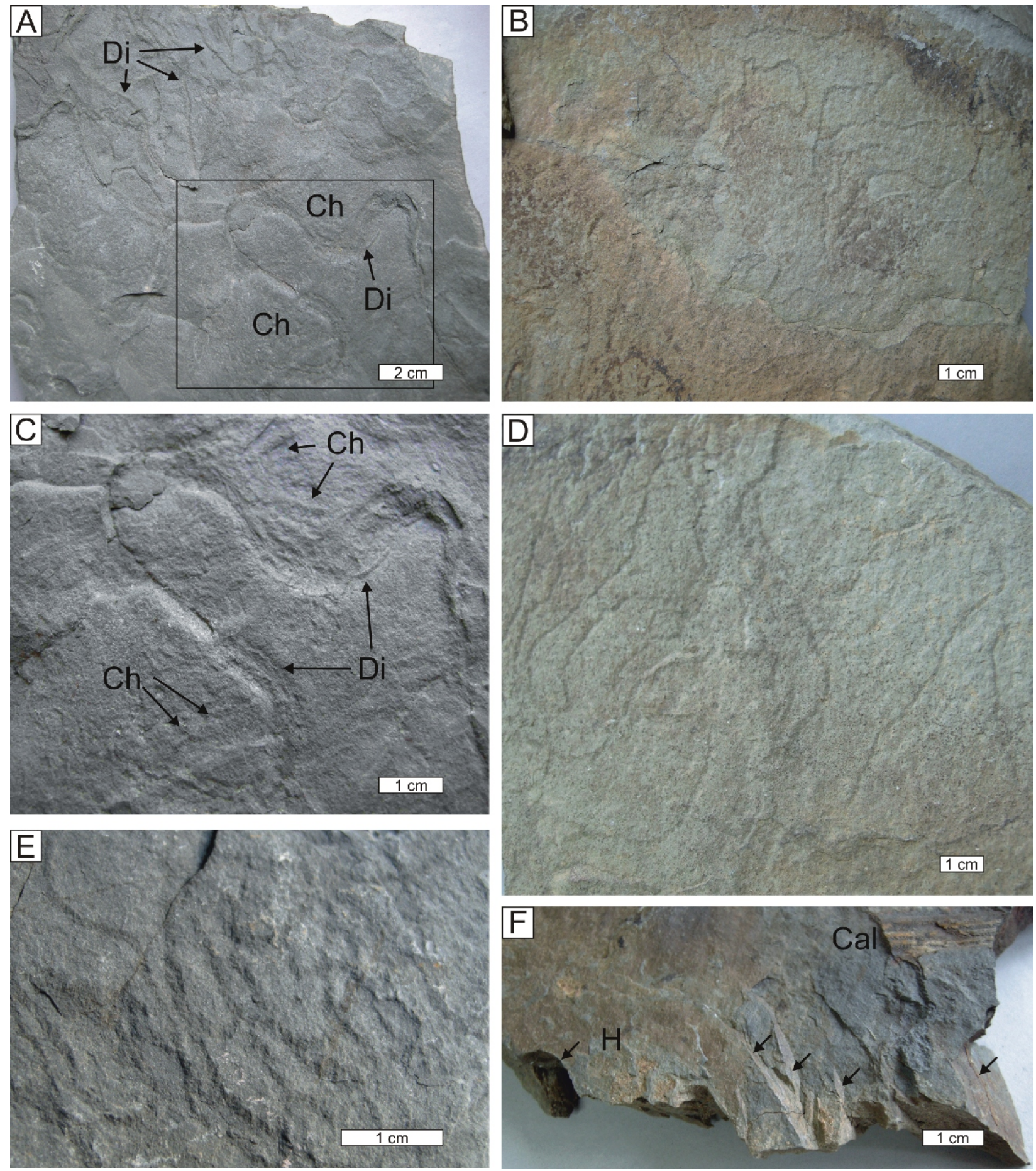

Fig. 6. Trace fossils from the Witoszów region

A-F - Dictyodora liebeana and Chondrites cf. intricatus, cross-sections on the bedding surface: A, C - abundant Dictyodora liebeana (Di) and tunnel cross-sections of $C$. cf. intricatus (Ch), cat. No. Wit IV/2a, C - enlarged view of the area marked by the square in A; B, D, E Dictyodora liebeana cross-sections of the spreite; B - cat. No. Wit I-1/1a; D - cat. No. Wit I-1/3; E - cat. No. Wit I-1/2a; F - visible vertical walls of $D$. liebeana marked by arrows, Cal - undetermined Calamitaceae, cat. No. Wit I-1/4b 
The stratigraphic range of Curvolithus is from the Proterozoic (Webby, 1970) to the Miocene (Buatois et al., 1998; Krobicki and Uchman, 2003; Hofmann et al., 2011). This ichnogenus commonly occurs in Carboniferous and Jurassic deposits (Eagar et al., 1985).

\author{
Ichnogenus Dictyodora Weiss, 1884 \\ Dictyodora liebeana (Geinitz, 1867) \\ (Figs. 5G-H, 6A-F and 10A-C)
}

Material and oc curre n c e.-Numerous incomplete specimens found in three exposures in the Witoszów region (Wit I, Wit II, Wit IV; samples no 4, 30 of Gunia, 1968 collection), one sample from the Lubiechów region (sample no. 41 of Gunia, 1968 collection) and the $D$. liebeana ichnofabric was observed on vertical polished sections. Several dozen specimens altogether.

D e s c r i p t i o n. - Complex three-dimensional spreiten structures, which are oriented mostly obliquely to the bedding. Horizontal cross-sections of the spreite are the most common finds. In such cases, the traces have the character of variously shaped asymmetrical and less often nearly symmetrical meanders; complex meanders (third-order at maximum) also occur. Their meandering pattern is irregular. Spacing between meanders is $0.3-20 \mathrm{~mm}$. Meanders often intersect (Figs. 5G and 6E). The spreite is $0.7-1.6 \mathrm{~mm}$ wide, generally $\sim 1 \mathrm{~mm}$. Typical basal burrow and mid-dorsal vertical walls are rarely preserved (Figs. $5 \mathrm{H}$ and $6 \mathrm{~A}, \mathrm{~B}, \mathrm{~F}$ ). The basal burrow is up to $10 \mathrm{~mm}$ wide (Fig. 6A). In side view, the wall shows fine longitudinal streaks (Fig. $5 \mathrm{H}$ ). This ichnospecies is regarded as the most complex Dictyodora form (see Benton, 1982).

$\mathrm{R}$ e $\mathrm{m}$ a r k s. - This ichnospecies represents the complex feeding trace of a shell-less mollusc (Benton and Trewin, 1980) or a worm-like animal (Benton, 1982). According to Seilacher (2007) the tracemaker of $D$. libeana explored deep tiers. Ethologically it is regarded as a fodinichnion (Buatois and Mángano, 2011), or as a deep-tier pascichnion (Uchman and Wetzel, 2012). This ichnospecies has been described mainly from deep-water strata of Europe, especially from the Lower Carboniferous Culm facies of Germany, Czech Republic and Spain (e.g., Roemer, 1870; Ruchholz, 1967; Benton, 1982; Stepanek and Geyer, 1989; Pek and Zapletal, 1990; Orr et al., 1996; Mikuláš et al., 2004). D. liebeana is typical of fine-grained, distal deposits with a high clay fraction and it is most often found in sediments of "roofing slate" type (Mikuláš et al., 2004). In the Sudetes, it has been recorded from the Mississippian Szczawno Formation of the Intra-Sudetic Basin (Żakowa, 1958; Muszer, 2013, 2019, 2020). This ichnospecies is of chronostratigraphic value, because its stratigraphic range is restricted to the Lower Carboniferous (Uchman, 2004, 2007a).

The ichnogenus Dictyodora ranges from the Ordovician to the Carboniferous and is considered typical of the deep-water Nereites ichnofacies (Benton, 1982; Baucon and Neto de Carvalho, 2008; Buatois and Mángano, 2011). Recently, it has also been described from Silurian and Devonian prodelta deposits in Argentina (Vieira de Luca and Basilici, 2013; Pazos et al., 2015b). New ichnological investigations (e.g., Pazos et al., 2015b; Muszer, 2013, 2019, 2020) show that the Paleozoic ichnogenus Dictyodora is abundant in mudstone deposits rich in nutrients, that formed below wave base, but not necessarily on a continental slope or in a bathyal environment. The most important evolutionary change of Dictyodora was an increase in the height of the wall, which led to an increase in size overall, and in complexity (Benton, 1982). The increase in regularity of meandering has been seen as evolution towards greater efficiency of feeding where food distribution was patchy (Seilacher, 1974).

Ichnogenus Diplopodichnus Brady, 1947

Diplopodichnus biformis Brady, 1947

(Figs. 5D-E and 9A)

Material and occurrence. - Four specimens from exposures Wit I and Wit II.

D e s c ri p t i o n. - Straight and curved horizontal trails, which are preserved as convex hyporeliefs, up to $7 \mathrm{~cm}$ long. One specimen is preserved as a single sinusoidal wave, which is slightly asymmetrical (Fig. 9A). Trails consist of two parallel ridges separated by a flat median groove, which is up to $2 \mathrm{~mm}$ wide. Median groove is wider than lateral ridges, which reach 1 $\mathrm{mm}$ width. Total trace width is $4 \mathrm{~mm}$. Trails are rather smooth, but in two specimens a subtle transverse "segmentation" is partly visible.

$\mathrm{R}$ e $\mathrm{m}$ a r k s. - The specimens from the Witoszów region are most similar to Diplopodichnus biformis described by Schatz et al. (2011: figs. 7, 8.2, 8.4, 9.1). This ichnogenus was originally defined by Brady (1947) from the Permian of Arizona, but Keighley and Pickerill (1996) emended the diagnosis. Diplopodichnus represents the repichnion ethological category (e.g., Pazos, 2002; Sadlok, 2008). According to many authors (e.g., Brady, 1947; Draganits et al., 2001; Getty et al., 2017; Lima et al., 2017) the producers of $D$. biformis were millipedes. As stated by Uchman et al. (2011) Diplopodichnus is similar to some variants of recent surface traces of isopods (benthic crustaceans). According to Braddy (1998), there is a "Diplichnites-Diplopodichnus-Dendroidichnites" spectrum that could have been made by the same tracemaker.

This ichnogenus is usually known from continental and nearshore environments (Lucas et al., 2004) of the Mermia and Scoyenia ichnofacies (Zhang et al., 1998; Lucas et al., 2013; Getty et al., 2017). It also occurs in the Upper Paleozoic diamictite and rhythmite facies in South America (Buatois and Mángano, 2011; Schatz et al., 2011; Netto et al., 2012b). The specimens from Witoszów are the first from a deep marine environment. The stratigraphic range of the ichnogenus is from the Ordovician to the Jurassic (Avanzini et al., 2011; Uchman et al., 2011a), and it covers a wide geographic area (Europe, USA, South America, India, China, see Zhang et al., 1998; Minter and Braddy, 2009; Avanzini et al., 2011; Schatz et al., 2011; Uchman et al., 2011; Lima et al., 2017; Getty et al., 2017).

\section{Ichnogenus Lockeia James, 1879}

Lockeia isp.

(Fig. 7A)

Material and occurrence. - Four specimens from exposure Wit II.

Description. - Small, elongate, oval to almond-shaped mounds preserved as convex hyporelief, with clear margins and pointed terminations. The traces are 10-13 mm long and 4-5 mm wide (Fig. 7A). Three specimens occur serially, one after the other, and all of them on the same bedding surface together with Protovirgularia isp. 
$\mathrm{R}$ e $\mathrm{m}$ a r k s. - Lockeia is usually interpreted as a bivalve resting trace (cubichnion; e.g., Häntzschel, 1975; Maples and Suttner, 1990; Ekdale and Bromley, 2001; Seilacher, 2007 Alonso-Muruaga et al., 2013), but some authors suggested its function as a domicile and escape trace (e.g., Buatois et al., 2005; Knaust, 2007). Other potential producers are ostracods and gastropods (e.g., Radley et al., 1998; Goldring et al., 2005). These traces occur in deposits representing a wide range of marine (from marginal to deep-sea) and freshwater environments from the Ediacaran to the Pleistocene (Kim, 1994; Radley et al., 1998; Goldring et al., 2005; Abbassi, 2007).

\section{Ichnogenus Lophoctenium Richter, 1850} ?Lophoctenium isp. (Fig. 7B)

Material and occurrence. - Two fragmentary specimens from exposure Wit II.

D e s c r i p t i o n. - Epichnial structures fragmentarily preserved on the bedding plane. They consist of a series of concentric, curved and closely spaced asymmetrical burrow-fills with furrows, displaying a spreiten-like structure. The fragments are up to $4 \mathrm{~cm}$ long and up to $6 \mathrm{~cm}$ wide. The traces resemble Lophoctenium comosum Richter described by Orr et al. (1996: fig. 8E, F) and occur in the same beds as Lockeia isp. The specimens are poorly preserved and their assignment is uncertain.

Re marks. - According to Uchman (1998) Lophoctenium needs a revision. This ichnogenus is regarded as a fodinichnion (trace of deposit-feeding organism, see Uchman et al., 2004). Lophoctenium occurs in flysch deposits (e.g., Książkiewicz, 1977; Uchman, 1998; Uchman et al., 2004) from the Ordovician (Häntzschel, 1975) to the Miocene (Uchman, 1995, 1998) and is often described from the Lower Carboniferous Culm facies (e.g., Benton, 1982; Stepanek and Geyer, 1989; Orr et al., 1996; Lehotský and Zapletal, 2007).

Ichnogenus Nereites Mac Leay in Murchison, 1839 Nereites isp.

(Fig. 10A, B)

Material and occurrence. - Two polished cross-sections of samples Cat. No. Wit II/8 and Wit IV/4 (exposures Wit II and Wit IV) with a Nereites ichnofabric.

Description. - The Nereites ichnofabric shows elongated, horizontal, dark "oval forms", enveloped by claystone material. These "oval forms" are up to $2 \mathrm{~cm}$ long and are attributable to cross-sections of tunnels of Nereites. The filling is formed by dark, fine-grained material, which differs from the host rock. This claystone material, probably reworked sediment, is a diagnostic feature of the ichnogenus Nereites (Uchman, 1995).

$\mathrm{R}$ e $\mathrm{m}$ a r k s. - Nereites is interpreted as internal meandering grazing trails (pascichnia) (e.g., Seilacher and Meischner 1965; Seilacher, 1986; Buatois and Mángano, 2011). The suggested possible producers were wormlike deposit-feeders, molluscs, arthropods or holothuroids (e.g., Häntzschel, 1975; Głuszek, 1998; Mángano et al., 2000; Joseph et al., 2012 and references therein).

This ichnogenus has been described from many occurrences ranging from the Late Precambrian (Crimes, 1987) to the Miocene (Uchman, 1995; Hu et al., 1998), or possibly Quaternary (Ekdale and Lewis, 1991).

It is a eurybathic form and a typical component of the Nereites ichnosubfacies, which is distributed in distal flysch facies (e.g., Uchman, 2007b; Olivero et al., 2009; Joseph et al., 2012). It also occurs on tidal flats (Mángano et al., 2000), in shallow-marine deposits (e.g., Crimes and Anderson, 1985; Seilacher, 2007) and in fresh-water lakes (Wetzel, 2002).

Ichnogenus Palaeophycus Hall, 1847

Palaeophycus tubularis Hall, 1847 (Fig. 7D-F)

Material and occurrence. - Several specimens from all exposures studied (Wit I, Wit II, Wit III and Wit IV).

D e s c r i p t i o n. - Predominantly horizontal to inclined endichnial burrows, distinctly lined, without ornamentation. They are preserved as convex epirelief and positive hyporelief, Tunnels are simple, cylindrical, straight to curved or undulating. They are up to $10 \mathrm{~cm}$ long, with a diameter of $1.5-6 \mathrm{~mm}$. The sediment fill is massive, similar to the host rock.

$\mathrm{R}$ e $\mathrm{m}$ a r k s. - This ichnogenus is eurybathic and occurs in various environments from freshwater to marine. It is described from the Proterozoic to the Recent (Häntzschel, 1975; Pemberton and Frey, 1982; Buatois and Mángano, 2011). Palaeophycus is ethologically interpreted predominantly as a dwelling burrow (domichnion) produced by deposit-feeders or predators, mostly by polychaetes, usually moving parallel to the bedding (e.g., Pemberton and Frey, 1982; Uchman, 1995; Mikuláš et al., 2013). Other authors have suggested fodinichnion/domichnion (e.g., Rodríguez-Tovar et al., 2010), or repichnion/domichnion (e.g., Chen et al., 2012).

Ichnogenus Phycosiphon Fischer-Ooster, 1858 Phycosiphon isp.

(Fig. 10A, B)

Material and occurrence. - Two polished cross-sections of samples Cat. No. Wit II/8 and Wit IV/4 (exposures Wit II and Wit IV) with a Phycosiphon ichnofabric.

D e s c r i p t i o n. - In polished sections, Phycosiphon resembles clusters of closely spaced elliptical spots and comma-shaped dots (0.2 $\mathrm{mm}$ thick) filled with darker sediments. In the specimens studied a narrow pale mantle was observed.

$\mathrm{R}$ e $\mathrm{m}$ a r k s. - The specimens studied are very similar to specimens of Phycosiphon incertum from the Eocene of Spitsbergen (Rodríguez-Tovar et al., 2014: fig. 3) and to small specimens of Phycosiphoniform burrows from Cretaceous turbidites in Mexico (Bednarz and Mcllroy, 2009: fig. 1.1).

The ichnogenus Phycosiphon has been variously described (for lists of synonyms see Fu, 1991; Goldring et al., 1991; Wetzel and Bromley, 1994). The Phycosiphon-producer generally colonized sediments enriched in organic matter (Wetzel, 2010) and was an opportunistic, highly selective deposit feeder (fodinichnion), but it remains unrecognized (Wetzel and Bromley, 1994; Wetzel and Uchman, 2001; Wetzel, 2008, 2010). According to Bednarz and Mcllroy (2009), producers of phycosiphoniform burrows were small, probably vermiform organisms. 

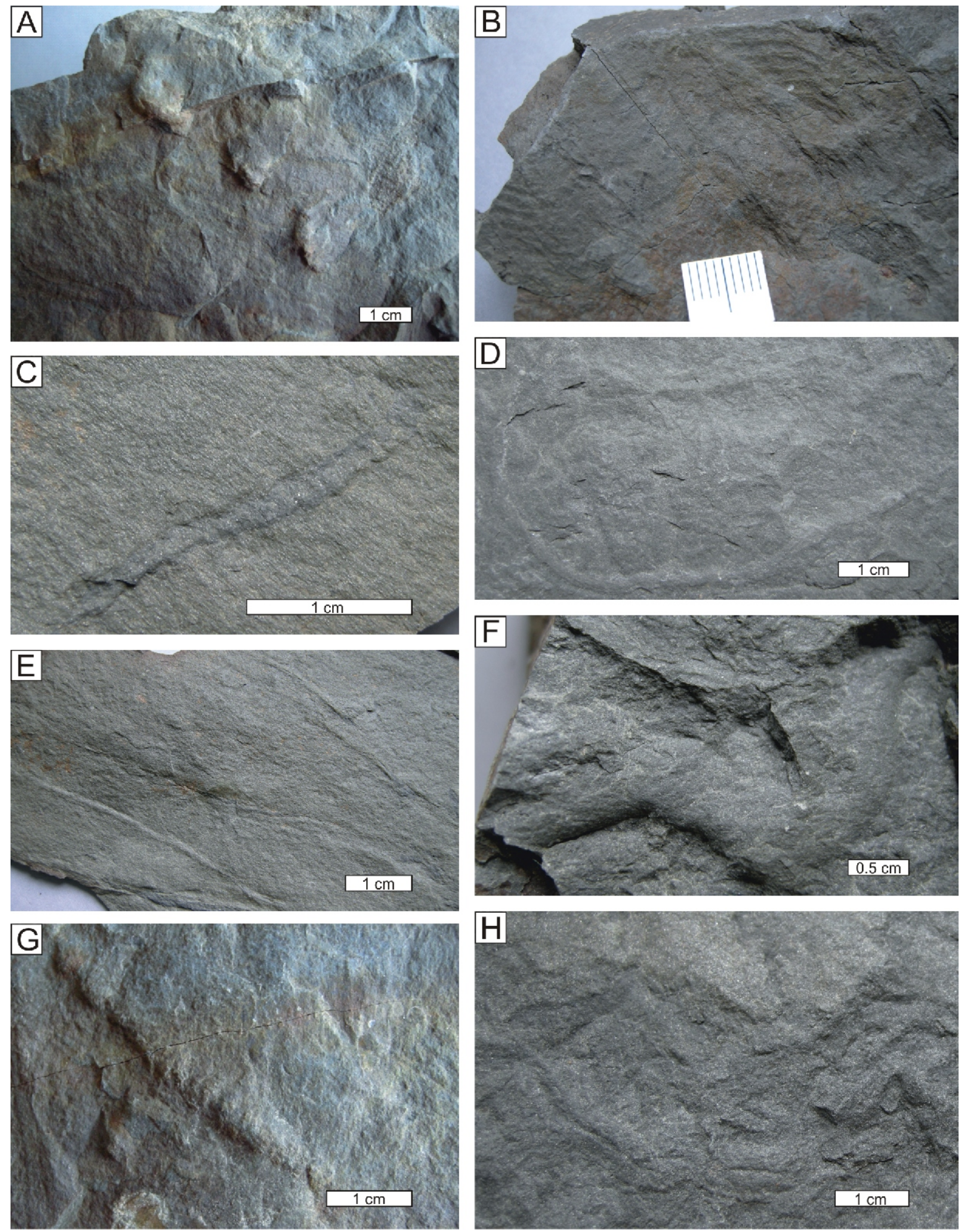

Fig. 7. Trace fossils from the Witoszów region

A - Lockeia isp. preserved as convex hyporelief, cat. No. Wit II/1b; B - ?Lophoctenium isp. preserved as epirelief, cat. No. Wit II/7; C Taenidium isp. preserved as epichnial burrow, cat. No. Wit III/1; D-F - Palaeophycus tubularis preserved as positive hyporelief: D - cat. No. Wit I-2/1, E - cat. No. Wit III/1, F - cat. No. Wit II/8; G - Protovirgularia isp. preserved as positive hyporelief, cat. No. Wit II/1b; H ?Psammichnites isp. preserved as positive hyporelief, cat. No. Wit II/1a 

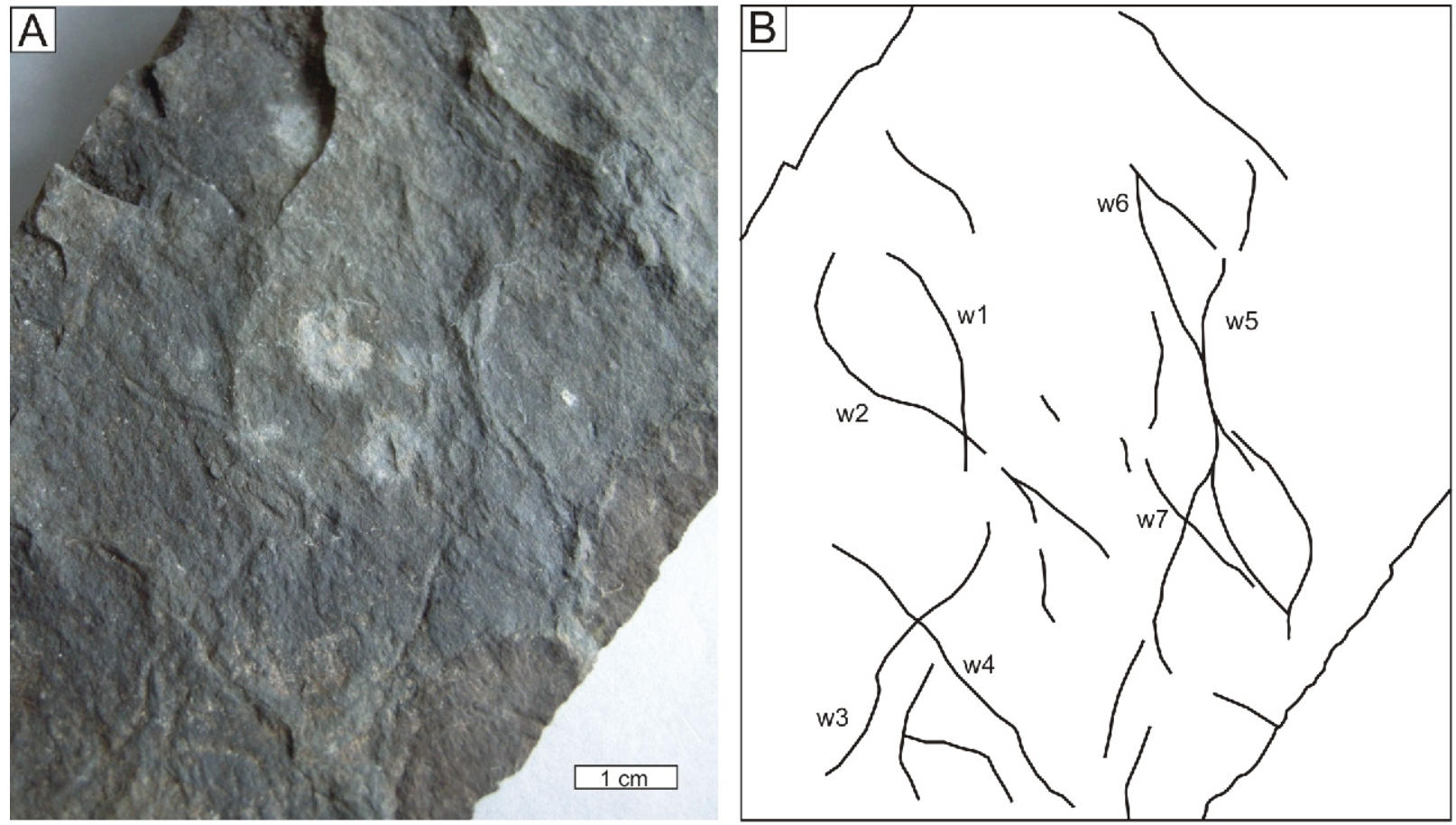

Fig. 8. Fish trails from the Witoszów region

A - Undichna cf. britannica preserved as negative epirelief on top of mudstone, cat. No. Wit I-z/2; B - line drawing of specimens in A with individual waves identified (w1-w7)

This ichnogenus is known from the Paleozoic to the Holocene from various marine environments (Seilacher, 1978; Fu, 1991; Goldring et al., 1991; Savrda et al., 2001; Naruse and Nifuku, 2008). It is most characteristic of the Nereites ichnofacies (Ineson, 1987) and the Zoophycos ichnofacies (Frey and Pemberton, 1984; Buatois and Mángano, 2011).

Ichnogenus Protovirgularia McCoy, 1850 Protovirgularia isp (Fig. 7G)

M a terial and occurrence. - Fragment of one specimen from exposure Wit II.

D e s c r i p t i o n. - Straight, unbranched, horizontal trail, which is poorly preserved (weathered) as convex hyporelief. It is $45 \mathrm{~mm}$ long and $4 \mathrm{~mm}$ wide. The internal structure consists of arcuate curved segments, highlighted by ribs. No visible median ridge. The trace is filled with sediment of the same type as the host rock. It occurs on the same bedding plane as Lockeia isp. and its width is similar to the width of Lockeia isp.

$\mathrm{R}$ e $\mathrm{m}$ a r k s. - This ichnogenus is ethologically classified as a locomotion trail of a deposit-feeding (repichnion) bivalve (Mángano et al., 2002b; Seilacher, 2007). It is known from various marine (shallow to deep) and freshwater deposits (Han and Pickerill, 1994 Nara and Ikari, 2011) from the Arenig to the Miocene (Uchman, 1998; Uchman and Gaździcki, 2006; Chen et al., 2011).
Material and occurrence. - Fragments of two specimens from exposures Wit II and Wit IV.

D e s c ri p t i o n. - Horizontal, unbranched, curved ribbon-shaped trails preserved as positive hyporeliefs. It is characterized by a narrow medial groove and two convex lobes. Traces are $6 \mathrm{~mm}$ wide and $2-4 \mathrm{~cm}$ long. Medial groove is thin and straight, $0.7 \mathrm{~mm}$ wide.

$\mathrm{R} \mathrm{e} \mathrm{m} \mathrm{a} \mathrm{r} \mathrm{ks.} \mathrm{-} \mathrm{These} \mathrm{trails} \mathrm{are} \mathrm{incomplete,} \mathrm{poorly} \mathrm{pre-}$ served, so their determination is very difficult. They show some resemblance to the ichnogenus Didymaulichnus, Young, 1972 (curving, smooth bilobate trails with distinct median furrow, preserved in convex hyporelief), but differs in features such as the lack of thin outer lateral bevels and of a meandering pattern (Zhu, 1997; Rodríguez-Tovar et al., 2014). Psammichnites was interpreted as a repichnion of large Paleozoic molluscs (Häntzschel, 1975). It is commonly referred to the feeding activity of a soft-bodied marine animal, moving through the sediment and being connected to the sediment surface by a snorkel device (e.g., Seilacher, 1997; Aceńolaza and Aceńolaza, 2006; Baucon and Neto de Carvalho, 2008).

It ranges from the Lower Cambrian probably to the Permian (see Mángano et al., 2002a). Psammichnites is often reported from marginal-marine environments (Mángano et al., 2002a; Buatois and Mángano, 2011; Desjardins et al., 2012), while the Carboniferous Psammichnites is listed as a common element of lower estuarine settings (Mángano et al., 2005; Buatois and Mángano, 2007). It also occurs in shale substrates in offshore settings and thick turbidite successions (see Álvaro and Vizcaiino, 1999).
Ichnogenus Psammichnites Torell, 1870 ?Psammichnites isp.

(Fig. $7 \mathrm{H}$ )
Ichnogenus Taenidium Heer, 1877

Taenidium isp.

(Fig. 7C) 

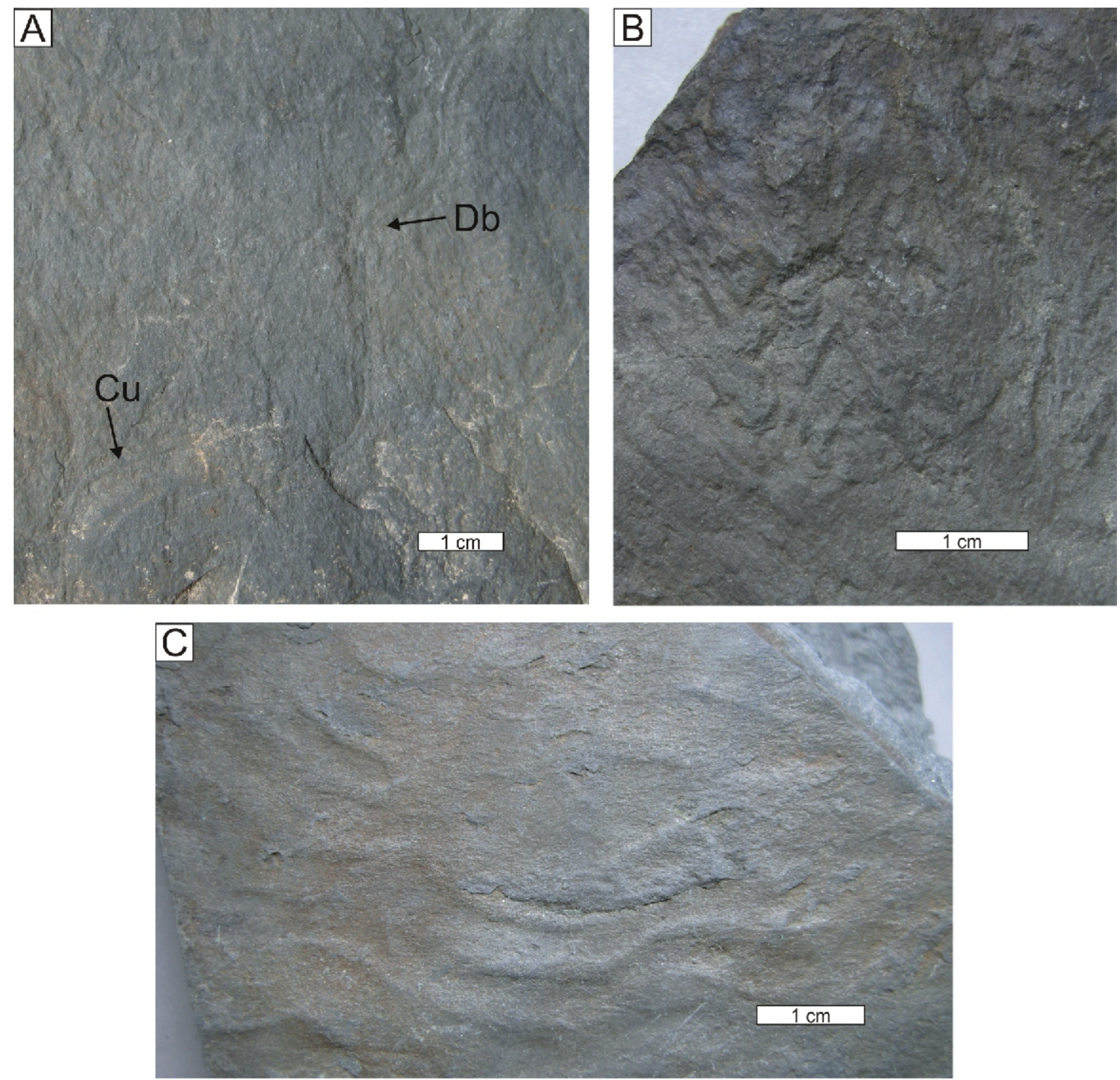

Fig. 9. Trace fossils and other structures from the Witoszów region

A - Diplopodichnus biformis (Db) and Curvolithus simplex (Cu) preserved as epirelief, cat. No. Wit l-z/2; B - zigzag scratches preserved as epirelief, cat. No. Wit III/2a; C - wave ripples influenced by microbial mats preserved as hyporelief, cat. No. Wit II/4b

Material and occurrence. - Fragment of one specimen from exposure Wit III.

D e s c ripti o n. - Horizontal, rather straight, slightly curved unwalled tunnel, preserved as an epichnial burrow on the bedding plane. It was actively filled, with a meniscate sandy core similar to the host rock, and a thin dark muddy lining. The lining is different than the host rock. The trace is $21 \mathrm{~mm}$ long and $2 \mathrm{~mm}$ wide.

R e marks. - The specimen resembles Taenidium barretti (Bradshaw, 1981) described by Baucon et al. (2014: fig. 4B), but is much thinner and menisci are less regular in shape and rather poorly preserved. The specimen studied is similar to Taenidium serpentinum Heer, 1877 in burrow width (see Keighley and Pickerill, 1994: fig. 3), but lacks well-spaced, arcuate menisci.

Meniscate burrows (ichnogenera Ancorichnus Heinberg, 1974; Beaconites Vialov, 1962; Taenidium Heer, 1877) were classified on the basis of the presence and type of wall, and differences in the type of meniscate backfilling (e.g., Bradshaw, 1981; Frey et al., 1984; D'Alessandro and Bromley, 1987). The ichnogeneric diagnosis of meniscate burrows was emended by
Keighley and Pickerill (1994). Unwalled Beaconites barretti was included by these authors in Taenidium Heer, 1877 as $T$. barretti. A new species of Taenidium was also described by Bromley et al. (1999).

Taenidium was produced probably by deposit feeders (Uchman, 2007b). According to Baucon et al. (2014) this burrowing style is typical of worm-like organisms. Taenidium is a combination of locomotion and feeding trace and could be regarded as a pascichnion. Ichnogenus Taenidium is a facies-crossing form (from freshwater to deep marine environments), ranging from the Ordovician to the Pleistocene (Keighley and Pickerill, 1994; Abbassi, 2007). Ichnospecies T. barretti is typical of continental settings, while $T$. serpentinum occurs only in marine deposits (Keighley and Pickerill, 1994: fig. 5).

VERTEBRATE TRACE FOSSILS

Ichnogenus Undichna Anderson, 1976 Undichna cf. britannica Higgs, 1988

(Fig. 8A, B) 

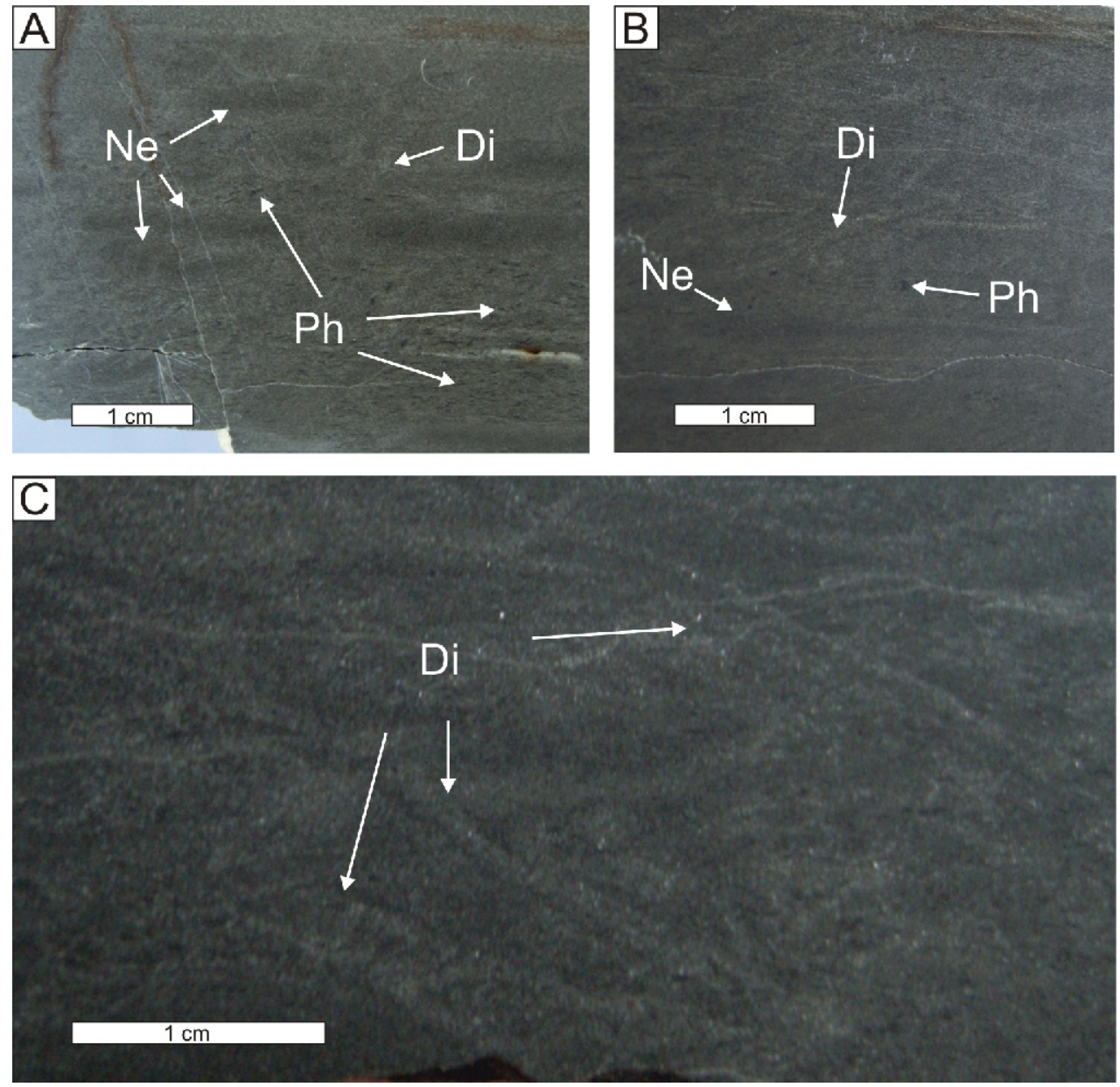

Fig. 10. Ichnofabric of Nereites isp., Phycosiphon isp. and Dictyodora liebeana

A, B - polished cross-sections with the Nereites (Ne), Phycosiphon isp. (Ph) and D. liebeana (Di) ichnofabrics: A - sample cat. No. Wit II/8, B - sample cat. No. Wit IV/4; C - polished cross-section of sample cat. No. Wit II/26 with Dictyodora liebeana (Di) ichnofabric

M a te rial a n d occurre n c e.-A few fragmentary specimens on one slab from exposure Wit I.

Description. - Horizontal trails, preserved as epichnial grooves, up to $6 \mathrm{~cm}$ long. The grooves are sharply incised and commonly $1 \mathrm{~mm}$ wide. Trails are commonly discontinuous, consisting of two intertwined sinusoidal or slightly sinusoidal waves with different amplitude and being out-of-phase. Because of fragmentary preservation the exact determination of its parameters is not possible. The probable wavelength is $\sim 30 \mathrm{~mm}$ and the amplitude is $7-10 \mathrm{~mm}$. It is difficult to distinguish the wider (larger) wave from the narrower (smaller) wave and to determine the phase difference between waves. In addition, on the same slab there are short sections of other waves or scratches.

$\mathrm{R}$ e $\mathrm{m}$ a r k s. - The morphotype of the trails described are most similar to specimens presented by Ronchi et al. (2018: fig. 7), but specimens from Witoszów are smaller. Similarly, specimens of Ronchi et al. (2018) are discontinuous and preserved only at the intersections of out-of-phase sinusoidal traces. The discontinuous and much larger specimens of $U$. britannica were also presented by Soler-Gijón and Moratalla (2001: fig. 3).

This ichnogenus was reviewed by Trewin (2000) and Minter and Braddy (2006) and its stratigraphic range was originally restricted to the Late Paleozoic (see Gibert et al., 1999). Subsequently, Undichna was reported from the Upper Silurian to the
Holocene as a common ichnotaxon in sub-aquatic continental and marine environments (Gibert et al., 1999; Minter and Braddy, 2006; Cardonatto and Melchor, 2014; Knaust and Minter, 2018; Knaust, 2019). According to Trewin (2000), Undichna occurs also within glacially influenced rhythmites and turbidites in non-marine basins.

Most records of $U$. britannica are known from the Carboniferous to the Jurassic (Ronchi et al., 2018), but the entire stratigraphic range of this ichnospecies is from the Upper Mississippian (Fillmore et al., 2011) to the Holocene (Gibert et al., 1999).

This trace fossil is produced by fish swimming close to the sediment surface (repichnion). According to Cardonatto and Melchor (2014) the potential producers of this trace are palaeonisciforms with a subcarangiform locomotion type.

\section{OTHER STRUCTURES}

Wave ripples influenced by microbial mats

$$
\text { (Fig. 9C) }
$$

Material and occurrence. - One example from exposure Wit II. 
D e s c ription. - The impression is preserved on bedding plane. It is $\sim 60 \mathrm{~mm}$ long and $25 \mathrm{~mm}$ wide. It is preserved as a set of hypichnial ridges, of which three ridges are clearly visible, but the other three ridges occur only as fragments. Ridges are sinuously and bilaterally symmetrical, wavy and $2 \mathrm{~mm}$ wide. Waves are of low-amplitude ( $5 \mathrm{~mm})$. The distance between ridges is constant, distinctive, as is the amplitude $(4-5 \mathrm{~mm})$. Wavelength is $\sim 22 \mathrm{~mm}$.

$\mathrm{R}$ e $\mathrm{m}$ a r k s. - This represents microbially induced sedimentary structures (MISS), in this case wave ripples. The specimen is very similar to the wave ripples described by Sarkar and Banerjee (2019) and Marriott et al. (2013: fig. 2a).

MISS are interpreted as matgrounds, which involved substrate modification by microbial activity (Noffke et al., 2001, 2006; Marriott et al., 2013; Pazos et al., 2015a; Vodrážková et al., 2019). According to Noffke et al. (2001) microbial mats dominated by cyanobacteria depend on photosynthesis. They are bathymetrically controlled and occur at the turning points of regression-transgression cycles from the Archean onwards. These structures, in modern times, are very common in shallow-marine to marginal-marine environments (Noffke et al., 2001, 2006). According to Davies et al. (2016), most of the fossil microbial mats have been reported from tidal and storm-influenced settings, and only sporadically from deeper water facies. Vodrážková et al. (2019) described microbially induced sedimentary structures from the Middle Devonian deep-water siliciclastic sequences of the Prague Basin and consider the origin of these structures as an effect of current and/or gravitational forces or of seismic shocks.

\section{Zigzag scratches}

(Fig. 9B)

Material and occurrence. - Fragment of one specimen from the exposure Wit III.

$\mathrm{D}$ e s $\mathrm{c} \mathrm{r}$ i p t i o $\mathrm{n}$. - The specimen is $4 \mathrm{~cm}$ long and $\sim 3 \mathrm{~cm}$ wide. It consists of sets of parallel zigzag scratches preserved as epirelief. Distances between scratches are not equal and reach $5 \mathrm{~mm}$. The specimen is poorly preserved and incomplete, and so determination is difficult.

$\mathrm{R}$ e $\mathrm{m}$ a r k s. - These zigzag scratches shows some resemblance to the ichnogenus Parundichna Simon et al., 2003, but do not show characters typical characteristic of this ichnogenus. Parundichna is interpreted as the swimming trace (repichnion) of a large coelacanth fish (Simon et al., 2003). The specimen studied may result from the motion of an unknown animal (fish or arthropod).

\section{ICHNOASSEMBLAGE AND PALAEOENVIRONMENTAL INTERPRETATION}

The ichnological material described from the Witoszów Górny region belongs to the Pogorzała Formation. Detailed sedimentological interpretations of this lithostratigraphic unit were made by Teisseyre (1956a) and Porebski (1981). The heterolithic succession was interpreted as reflecting deltaic-marginal marine environments (Cramer et al., 1924; Teisseyre, 1968b; Gunia, 1968). Other authors consider the Pogorzała Formation as deposits of a fan-delta slope/basin plain depositional system (Nemec et al., 1980; Porębski, 1981, 1987). According to Wojewoda (2014, 2016a, b), the heterolithic succession represents turbidites, hemipelagic and pelagic facies with complexes of redeposited older rocks (often Devonian).

The mudstones from Witoszów Górny have a characteristic dark colour (dark grey, grey, green grey), and include pyrite concretions and well-developed thin parallel lamination. Other sedimentary structures were not observed, with the exception of one specimen of wave ripples. The mudstones are intercalated with thin fine-grained greywackes $1-20 \mathrm{~cm}$ thick. These rocks correspond to association I described by Porębski (1981). Such lithological features of mudstones are characteristic of low-energy lower-offshore settings (see Pemberton et al., 2012) and deeper settings (slopes and deep-sea fans; see Hubbard et al., 2012; Uchman and Wetzel, 2012). Their sedimentation took place in low-energy and low-oxygenated waters below storm wave base, with periodically anaerobic conditions. The fine-grained greywackes may represent storm deposits. Some plant fossils (Fig. 4A-D), poor preserved benthic (bivalves) and nektonic (cephalopods, fish) macrofauna (Fig. 4E-I) also occur. The macrofauna indicate an open marine environment and the plant fragments were probably transported from land to sea by rivers or by floating.

An abundant and moderately diverse ichnofauna (fifteen ichnospecies, Table 1), found in four exposures studied (Wit IWit IV) in the Witoszów Górny region allows additional palaeoenvironmental conclusions. Among these trace fossils fodinichnia and repichnia dominate, while pascichnia, domichnia and cubichnia are subordinate. Dictyodora liebeana is the most common trace fossil and occurs in three exposures (Wit I, Wit II and Wit IV). This ichnospecies was also found in the collection of Gunia (1968), including his outcrop 41 (Lubiechów region, the Pogorzała Formation), which was not studied here. Palaeophycus tubularis occurs frequently in all exposures studied. Other invertebrate trace fossils were occasionally found: Archaeonassa fossulata, Archaeonassa isp., Chondrites cf. intricatus, Curvolithus simplex, Diplopodichnus biformis, Lockeia isp., ?Lophoctenium isp., Nereites isp., Phycosiphon isp., Protovirgularia isp., ?Psammichnites isp. and Taenidium isp. In exposure Wit I fish swimming trails Undichna cf. britannica were also found. An uncertain zigzag structure was discovered only in exposure Wit III.

The trace fossil assemblages from individual exposures differ from each other to varying degrees, but three of them are quite similar, primarily due to abundant $D$. liebeana. The highest taxonomic diversity (Table 1) was observed in shales from the exposures Wit II (10 ichnotaxa) and Wit I (8 ichnotaxa). In mudstones from exposure Wit IV 7 ichnotaxa were found. Trace fossil assemblages from these 3 exposures show the greatest similarity ( 4 or 5 common ichnotaxa) and display a Dictyodora liebeana ichnoassemblage. A very poor trace fossil assemblage with the lowest ichnotaxonomic diversity occurs in exposure Wit III (only 3 ichnotaxa, 1 ichnospecies common), the only exposure in which $D$. liebeana was not discovered.

Ichnological studies from Witoszów Górny also included ichnofabric analysis of some mudstone samples with $D$. liebeana. This involved observation of all structural and textural aspects of the deposits, especially bioturbation. In several polished cross-sections Nereites, Phycosiphon and D. liebeana ichnofabrics are observed (Fig. 10A-C). The Phycosiphon ichnofabric (small, dark, flattened "spots" and strings) manifests deeper tiering than the Nereites ichnofabric (horizontal, elongated and dark "forms", enveloped by claystone material; Fig. 10A). In contrast to the observations of Mikuláš et al. (2002), the Dictyodora ichnofabric (the deepest tiering) from Witoszów shows clearly visible courses of these traces, which are oriented obliquely to the bedding surface (Fig. 10C). They are lined with a thin dark coating. 
Ta ble 1

List of trace fossils from the Witoszów Górny region

\begin{tabular}{|l|c|c|c|c|}
\hline \multicolumn{1}{|c|}{ Trace fossils } & Wit I & Wit II & Wit III & Wit IV \\
\hline Archaeonassa fossulata & + & & & \\
\hline Archaeonassa isp. & + & & & + \\
\hline Chondrites cf. intricatus & + & & & + \\
\hline Curvolithus simplex & + & + & & \\
\hline Dictyodora liebeana & +++ & +++ & & +++ \\
\hline Diplopodichnus biformis & + & + & & \\
\hline Lockeia isp. & & + & & \\
\hline ?Lophoctenium isp. & & + & & \\
\hline Nereites isp. & & + & & + \\
\hline Palaeophycus tubularis & ++ & + & ++ & ++ \\
\hline Phycosiphon isp. & & + & & + \\
\hline Protovirgularia isp. & & + & & \\
\hline ?Psammichnites isp. & & + & & + \\
\hline Taenidium isp. & & & + & \\
\hline Undichna cf. britannica & + & & & + \\
\hline Zigzag structures & & & + & \\
\hline
\end{tabular}

+++ - very abundant, ++ - abundant, + - rare

The palaeoenvironmental interpretation of sedimentary conditions of Witoszów mudstones is primarily based on the most common and distinctive trace fossil, $D$. liebeana. This ichnospecies has specific palaeoenvironmental requirements. Uchman (2004) stated that Ordovician to Carboniferous deep-marine ichnofaunas typically contained Dictyodora. According to Buatois and Mángano (2011 and references therein) this ichnogenus is considered as typical of deep-water Nereites ichnofacies, but later research proved that Dictyodora occurs also in mudstones in a prodelta setting (see Pazos et al., 2015b). According to Pazos et al. (2015b), Dictyodora is not a direct indicator of deep-sea environments and most Dictyodora ichnospecies from the Silurian of Argentina are probably frequent in muddy substrates rich in nutrients below storm wave base, but not necessarily slope or bathyal.

In the Witoszów region, $D$. liebeana coexists with Nereites isp. The ichnogenera Lophoctenium, Chondrites and Undichna are also present in the Nereites ichnofacies (Buatois and Mángano, 2011; Knaust, 2019). Other trace fossils from the Witoszów mudstones show varying environmental preferences. The ichnogenera Palaeophycus, Lockeia and Protovirgularia are eurybathic, while Archaeonassa, Curvolithus and Psammichnites mainly characterize shallow water Cruziana ichnofacies but may also be present in deeper sedimentation zones. Only Diplopodichnus has so far been described from continental and near marine environments from the Mermia and Scoyenia ichnofacies (Lucas et al., 2004; Buatois and Mángano, 2011). These ichnogenera, with the exception of Dictyodora and Palaeophycus, occur sporadically. According to Uchman and Wetzel (2011), co-occurrence of deep-sea and shelf trace fossils may be caused by the transport of trace-makers by storm and other currents from the shelf to the deep sea.

The Nereites ichnofacies, documented from flysch deposits (Buatois and Mángano, 2011, and references therein), is characterized by a dominance of graphoglyptids and the presence of sophisticated grazing trails, feeding traces and deposit feeders, the dominance of shallow-tier trace fossils, very high ichnodiversity and high ichnoabundance, but low densities of individual ichnotaxa. This characteristic refers rather to the Nereites ichnofacies from the Mesozoic-Cenozoic. Some ichnogenera and ichnofacies showed evolutionary changes through the Phanerozoic (Buatois and Mángano, 2011). For example, the evolutionary trend of Dictyodora was manifested by increase in the height of the wall, which led to an increase in size overall and in complexity (Benton, 1982). In consequence, these changes resulted in increased efficiency of feeding where food distribution was patchy (Seilacher, 1974). The Nereites ichnofacies changed many times, including by progressive size decrease of its components, increase in diversity and increase in the degree of complexity of some of the trace fossils (Seilacher, 1974; Uchman, 2003, 2004). This ichnofacies occurs over a wide bathymetric range (see examples in Uchman and Wetzel, 2012). The deep-sea trace fossils have often changed (e.g., in the diversity and contribution of graphoglyptids) through the Phanerozoic (Uchman, 2003, 2004). Cambrian graphoglyptids are known only from shelf deposits, whereas in the Ordovician this group colonized the deep sea floor (Orr, 2001; Uchman and Wetzel, 2012).

The Dictyodora liebeana ichnoassemblage from the Witoszów mudstones with dominant $D$. liebeana (exposures Wit I, Wit II and Wit IV) represents the non-standard Nereites ichnofacies (sub-ichnofacies Nereites, which is characteristic of mud-rich distal flysch; see Seilacher, 1974), because graphoglyptids (a typical component of this ichnofacies) have not yet been found in this region. One reason for the absence of graphoglyptids may be because generally the diversity and frequency of this group are low from the Cambrian to the Middle Jurassic (Uchman, 2003). Another explanation is that sedimentation of mudstones from Witoszów took place in slightly shallower conditions than deep-marine, and so not conducive to the development of graphoglyptids, or the graphoglyptids were not preserved.

According to Seilacher (1977), graphoglyptids are hollow and they can easily be destroyed by compaction and therefore need special conditions for preservation. They commonly occur in areas where the erosional effects of turbidity currents are low and bioturbation and tiering of organisms within the sea-floor sediments is reduced (Wetzel, 1984). Graphoglyptids represent agrichnia and are the best example of K-selected ichnotaxa (see Ekdale, 1985), which are produced by animals adapted to a stable environment with low or moderate ecological stress (Uchman and Wetzel, 2011). According to Hovikoski et al. (2018), the occurrence of graphoglyptids is usually referred to stable uniform conditions, while unstable physico-chemical conditions on the sea floor were limiting factors responsible for the absence of this group of trace fossils. An additional factor that protected the area from colonization by some, typically deep-sea, trace makers, was isolation of the basin from the open ocean (Hovikoski et al., 2018).

The absence of graphoglyptids from this region suggests that these rocks were deposited rather in prodelta settings than on a basin plain. A similar ichnoassemblage with Dictyodora, Nereites, Zoophycos, microbial mat structures and without graphoglyptids was described from the Silurian pro-delta deposits of Argentina by Pazos (2015a, b). Additionally, relatively numerous plant remains implies not too great a distance from a continental area. It has been demonstrated that the Nereites ichnofacies may extend into sub-neritic environments during rapid shallowing (Uchman et al., 2004) and relatively shallow-water delta-fed turbidite systems (Olivero et al., 2010).

The nearest sites with Dictyodora liebeana are in the upper Mississippian Szczawno Formation in the Intra-Sudetic Basin (Muszer, 2013, 2020). However, this ichnotaxon is scarce there and the ichnoassemblages are different with more shallow-marine ichnotaxa. For example, the Piaskowa Góra succession 
(Muszer , 2020) was formed in an environment intermediate between a lower offshore zone (the distal Cruziana ichnofacies) and a fan-delta slope (below wave base, the Zoophycos ichnofacies).

An ichnoassemblage described by Orr et al. (1996) from the Lower Carboniferous of Menorca shows great similarity to the ichnoassemblage described from Witoszów. It occurs in the Culm sediments (mainly in sandstones, siltstones, mudstones) interpreted mostly as deposits of an inner- to mid-fan palaeoenvironment. A diverse ichnofauna contains $D$. liebeana, Chondrites, Lophoctenium, Nereites, Neonereites, Arthrophycus, Phycosiphon, Tomaculum (formerly Syncoprulus). In this ichnoassemblage, graphoglyptids are also absent.

A similar ichnoassemblage with Dictyodora was described by Benton (1982) from the Lower Carboniferous of Thuringia. It occurs in rhythmically layered black sapropelic mudstones and greywackes (the Culm facies). This ichnoassemblage represents the Nereites ichnofacies and contains also Chondrites, Lophoctenium, Protovirgularia and Nereites, but also Phycosiphon and the graphoglyptid Paleodictyon.

Another similar Dictyodora-Nereites ichnoassemblage occurs in the Carboniferous of the Carnic Alps (Baucon and Neto de Carvalho, 2008) and is interpreted as corresponding to deep marine settings associated with delta-front, organic-rich muds. It includes Dictyodora, Nereites and Protopalaeodictyon as an accessory component. Additionally, this fine-grained deposit is also characterized by presence of plant remains.

Two Carboniferous ichnoassemblages with Dictyodora liebeana are also known from Moravia and Silesia (Zapletal and Pek, 1987; Mikuláš et al., 2002, 2004). In the first one, this ichnospecies is accompanied by the ichnogenera Chondrites, Phycosiphon, Planolites, Spirodesmos, Falcichnites, Pilichnus, Protopaleodictyon and Zoophycos. The second ichnoassemblage contains, in addition to Dictyodora, Diplocraterion, Rhizocorallium, Cosmoraphe and Paleodictyon. Mikuláš et al. (2002) also described ichnofabrics of the Culm facies from Moravia and Silesia, containing $D$. liebeana.

The ichnoassemblage studied shows some similarities (the presence of Dictyodora liebeana, Nereites, Chondrites and Phycosiphon) and differences (the lack of graphoglyptids) to other Mississippian ichnoassemblages from the European Culm facies. This may be the result of limited connection of the Świebodzice basin with the open ocean as well as unstable environmental settings caused by a rapidly subsiding basin (see Nemec et al., 1980; Porębski, 1981, 1987, 1990) in the Late Visean-Serpukhovian.

The lithological features of the mudstones (e.g., dark colour, pyrite concretions, lamination) from Witoszów Górny, the poverty of benthic and nektonic macrofauna and numerous trace fossils typical of the Nereites ichnofacies, but without graphoglyptids, testify to their deposition in a deeper sedimentation zone, below storm wave base, most likely in dysaerobic (and even anaerobic), pro-delta conditions. Domination of deposit feeders in the Dictyodora ichnoassemblage and the absence of suspension feeders indicates a soft, easy-to-penetrate and organic-rich substrate.

\section{CONCLUSIONS}

This is the first comprehensive report of trace fossils from the Pogorzała Formation and the Świebodzice Unit. In four studied exposures in Witoszów Górny, abundant and moderately diverse
(15 ichnospecies referred to 14 ichnogenera) ichnofauna were discovered and within them 1 ichnospecies of fish swimming trails. Wave ripples influenced by microbial mats and zigzag structures were also found. The Dictyodora liebeana ichnoassemblage, which occurs in dark green grey mudstones in three studied exposures (Wit I, Wit II and Wit IV) represents the non-standard Nereites ichnofacies (probably Nereites sub-ichnofacies) without complex agrichnial burrows. An absence of graphoglyptids may be the result of many factors: (1) low diversity and frequency of this group, (2) shallower conditions, which were not conducive to the development of graphoglyptids or their preservation, (3) unstable conditions caused by the rapidly subsiding Świebodzice basin in the Late Visean-Serpukhovian and (4) limited connection of the basin with the open ocean. $D$. liebeana has also been found in the Lubiechów region (sample 41, coll. of Gunia, 1968). The above-mentioned four occurrences of $D$. liebeana have a zonal, latitudinal course and are located in the south of the Pogorzała block (Fig. 1).

Lithological features of the mudstones, the poverty of benthic and nektonic macrofauna, plant remains and numerous trace fossils without graphoglyptids indicate deposition of these strata in a deeper marine settings, below storm wave base, most likely in dysaerobic (and even anaerobic), pro-delta conditions. A domination of deposit feeders and absence of suspension feeders in the ichnoassemblage described indicates a soft, organic-rich and easy-to penetrate mud substrate. These mudstones represent distal flysch.

Among the trace fossils listed, the most important stratigraphically is $D$. liebeana, which is an index for the Lower Carboniferous (Uchman, 2004, 2007a). Occurrence of this ichnospecies in the Serpukhovian of the neighbouring the Intra-Sudetic Synclinorium (Żakowa, 1958; Muszer, 2013; 2020; Muszer et al., 2016) indicates that it is restricted to the Mississippian. An other ichnospecies which appeared in the Carboniferous is Undichna britannica (see Fillmore et al., 2011; Ronchi et al., 2018). The widespread occurrence of $D$. liebeana and presence of $U$. cf. britannica in-situ in the region of Witoszów Górny supports the latest suggestions of Pluta and Górecka-Nowak (2018) and provides additional evidence for referring the mudstones of the Pogorzała Formation to the Mississippian.

Many researchers have emphasized the difficulty of stratigraphic correlation of the rocks building the Świebodzice Unit, because of the lack of good biostratigraphic control, and of widespread correlative horizons (e.g., Teisseyre, 1956a; Porębski, 1981; Pluta and Górecka-Nowak, 2018). The results of this ichnological study suggest that one such correlative horizon may be the strata containing Dictyodora liebeana. This ichnospecies, restricted to the Mississippian, is abundant and easy to recognize, especially in the field.

Further ichnological studies of the Pogorzała Formation (e.g., in the vicinity of Lubiechów), especially of the mudstones and sandstones, may provide additional palaeoenvironmental information. Likewise, ichnological studies of the Pełcznica Formation may be prospective.

Acknowledgements. This research was financed by research subsidy UWr 2019/501. D. Knaust and an anonymous reviewer are thanked for their helpful comments and suggestions. Special thanks are due to my husband Antoni for help in the fieldwork. 


\section{REFERENCES}

Abbassi, N., 2007. Shallow marine trace fossils from Upper Devonian sediments of the Kuh-e Zard, Zefreh area, Central Iran. Iranian Journal of Science and Technology, 31: 23-33.

Aceñolaza, G., Aceñolaza, F., 2006. Nereites saltensis (trace fossil): a taxonomical reevaluation of type and additional material from the Puncoviscana Formation of NW Argentina (Ediacaran-Early Cambrian). In: V South American Symposium on Isotope Geology (eds. C. Gaucher and J. Bossi). Short Papers: 218-220. Punta del Este, Uruguay.

Alonso-Muruaga, P.J., Buatois, L.A., Limarino, C.O., 2013 Ichnology of the Late Carboniferous Hoyada Verde Formation of western Argentina: exploring postglacial shallow-marine ecosystems of Gondwana. Palaeogeography, Palaeoclimatology, Palaeoecology, 369: 228-238.

Álvaro, J.J., Vizcaïno, D., 1999. Biostratigraphic significance and environmental setting of the trace fossil Psammichnites in the Lower Cambrian of the Montagne Noire, France. Bulletin de la Société Géologique de France, 170: 821-828.

Anderson, A., 1976. Fish trails from the Early Permian of South Africa. Palaeontology, 19: 397-409.

Avanzini, M., Contardi, P., Ronchi, A., Santi, G., 2011 Ichnosystematics of the Lower Permian invertebrate traces from the Collio and Mt. Luco Basins (North Italy). Ichnos, 18: 95-113.

Baucon, A., Neto de Carvalho, C., 2008. From the river to the sea Pramollo, a new ichnolagerstätte from the Carnic Alps (Carboniferous, Italy-Austria). Studi Trentini di Scienze Naturali, Acta Geologica, 83: 87-114.

Baucon, A., Ronchi, A., Felletti, F., Neto de Carvalho, C., 2014 Evolution of Crustaceans at the edge of the end-Permian crisis: Ichnonetwork analysis of the fluvial succession of Nurra (Permian-Triassic, Sardinia, Italy). Palaeogeography, Palaeoclimatology, Palaeoecology, 410: 74-103.

Baucon, A., Bednarz, M., Dufour, S., Felletti, F., Malgesini, G., De Carvalho, C.N., Niklas, K.J., Wehrmann, A., Batstone, R. Bernardini, F., Briguglio, A., Cabella, R., Cavalazzi, B. Ferretti, A., Zanzerl, H., Mcllroy, D., 2020. Ethology of the trace fossil Chondrites: form, function and environment. Earth-Science Reviews, 202: doi.org/10.1016/j.earscirev.2019.102989

Bederke, E., 1924. Das Devon in Schlesien und das Alter der Sudetenfaltung. Fortschritte der Geologie und Palaeontologie, 7: $1-50$

Bednarz, M., Mcllroy, D., 2009. Three dimensional reconstruction of "phycosiphoniform" burrows: implications for identification of trace fossils in core. Palaeontologia Electronica, 12, http://palaeo-electronica.org/2009_3/195/index.html

Benton, M.J., 1982. Dictyodora and associated trace fossils from the Palaeozoic of Thuringia. Lethaia, 15: 115-132.

Benton, M.J., Trewin, N.H., 1980. Dictyodora from the Silurian of Peebleshire, Scotland. Palaeontology, 23: 501-513.

Berg, G., Dathe, E., Zimmermann, E., 1910. Geologische Karte von Preussen und benachbarten Bundesstaaten, 1:25000. Blatt Friedland in Schlesien, Berlin.

Braddy, S.J., 1998. An overview of the invertebrate ichnotaxa from the Robledo Mountains ichnofauna (Lower Permian), southern New Mexico. New Mexico Museum of Natural History and Science Bulletin, 12: 93-98.

Bradshaw, M.A., 1981. Paleoenvironmental interpretations and systematics of Devonian trace fossils from the Taylor Group (lower Beacon Supergroup), Antarctica. New Zealand Journal of Geology and Geophysics, 24: 615-652.

Brady, L.F., 1947. Invertebrate tracks from the Coconino Sandstone of northern Arizona. Journal of Paleontology, 21: 466-472.

Bromley, R.G., 1996. Trace Fossils: Biology, Taphonomy and Applications. 2nd edition. Chapman and Hall, London.

Bromley, R.G., Ekdale, A.A., Richter, B., 1999. New Taenidium (trace fossil) in the Upper Cretaceous chalk of northwestern Europe. Bulletin of the Geological Society of Denmark, 46: 47-51.
Brongniart, A.T., 1823. Observations sur les Fucoïdes, et sur quelques autres plantes marines fossils. Mémoires de la Societé d'Histoire Naturelle de Paris, 1: 301-320.

Buatois, L.A., Mángano, M.G., 2002. Trace fossils from Carboniferous floodplain deposits in western Argentina: implications for ichnofacies models of continental environments. Palaeogeography, Palaeoclimatology, Palaeoecology, 183: 71-86.

Buatois, L.A., Mángano, M.G., 2007. Invertebrate ichnology of continental freshwater environments. In: Trace Fossils. Concepts, Problems, Prospects (ed. W. III Miller): 285-323. Elsevier, Italy.

Buatois, L.A., Mángano, M.G. (eds.), 2011. Ichnology. OrganismSubstrate Interactions in Space and Time. Cambridge University Press.

Buatois, L.A., Mangano, M.G., Mikuláš, R., Maples, C.G., 1998 The ichnogenus Curvolithus revisited. Journal of Palaeontology, 72: 758-769.

Buatois, L.A., Gingras, M.K., MacEachern, J., Mangano, M.G., Zonnveld, J.P., Pemberton, S.G., Netto, R.G., Martin, A., 2005. Colonization of brackish-water systems through time: evidence from the trace-fossil record. Palaios, 20: 321-347.

Buckman, J.O., 1994. Archaeonassa Fenton and Fenton 1937 reviewed. Ichnos, 3: 185-192.

Cardonatto, M.C., Melchor, R.N., 2014. Biomechanical analysis of fish swimming trace fossils (Undichna): preservation and mode of locomotion. Topics in Geobiology, 41: 265-303.

Carmona, N.B., Ponce, J.J., Mangano, M.G., 2006. Variability of the Glossifungites ichnofacies at the boundary between the Sarmiento Formation (middle Eocene-early Miocene) and Chenque Formation (early Miocene) in San Jorge Gulf, Chubut, Argentina. Ameghiniana, 43: 413-425.

Chen, Z.-Q., Fraiser, M.L., Bolton, C., 2012. Early Triassic trace fossils from Gondwana Interior Sea: implications for ecosystem recovery following the end-Permian mass extinction in south high-latitude region. Gondwana Research, 22: 238-255.

Chen, Z.-Q., Tong, J., Fraiser, M.L., 2011. Trace fossil evidence for restoration of marine ecosystems following the end-Permian mass extinction in the Lower Yangtze region, South China. Palaeogeography, Palaeoclimatology, Palaeoecology, 299: 449-474.

Cramer, R., Finckh, L., Zimmermann, E., 1921. Geologische Karte von Preussen und benachbarten Bundesstaaten, 1: 25000, Blatt Freiburg.

Cramer, R., Finckh, L., Zimmermann, E., 1924. Erläuterungen zur geologische Karte, Blatt Schweidnitz: 3-51. Berlin.

Crimes, T.P., 1987. Trace fossils and correlation of late Precambrian and early Cambrian strata. Geological Magazine, 124: 97-119.

Crimes, T.P., 1992. Changes in the trace fossil biota across the Proterozoic-Phanerozoic boundary. Journal of the Geological Society, 149: 637-646.

Crimes, T.P., Anderson, M.M., 1985. Trace fossils from the late Precambrian-early Cambrian strata of southeastern New Foundland (Canada): temporal and environmental implications. Journal of Palaeontology, 59: 310-343.

D’Alessandro, A., Bromley, R.G., 1987. Meniscate trace fossils and the Muensteria-Taenidium problem. Palaeontology, 30: 743-763.

Dames, E., 1868. Über die in der Umgebung Freiburgs in Nieder-Schlesien auftretenden devonischen Ablagerrungen. Zeitschrift der Deutschen Geologischen Gesellschaft, 20: 469-508.

Davies, N.S., Liu, A.G., Gibling, M.R., Miller, R.F., 2016. Resolving MISS conceptions and misconceptions: a geological approach to sedimentary surface textures generated by microbial and abiotic processes. Earth-Science Reviews, 154: 210-246.

Demircan, H., Uchman, A., 2016. Ichnology of prodelta deposits of the Mezardere Formation (late Eocene - early Oligocene) in the 
Gökçeada Island, western Turkey. Geodinamica Acta, 28: 86-100.

Desjardins, P.R., Buatois, L.A., Mángano, M.G., 2012. Tidal flats and subtidal sand bodies. Developments in Sedimentology, 64 529-561.

Draganits, E., Braddy, S.J., Briggs, D.E.G., 2001. A Gondwanan coastal arthropod ichnofauna from the Muth Formation (Lower Devonian, Northern India): paleoenvironment and tracemaker behavior. Palaios, 16: 126-147.

Eagar, R.M.C., Baines, J.G., Collinson, J.D., Hardy, P.G., Okolo, S.A., Pollard, J.E., 1985. Trace fossil assemblages and their occurrence in Silesian (Mid-Carboniferous) deltaic sediments of the Central Pennine Basin, England. SEPM Special Publication, 35: 99-149.

Ekdale, A.A., 1985. Paleoecology of the marine endobenthos. Palaeogeography, Palaeoclimatology, Palaeoecology, 50: $63-81$.

Ekdale, A.A., Bromley, R.G., 2001. A day and a night in the life of a cleft-foot clam: Protovirgularia-Lockeia-Lophoctenium. Lethaia, 34: 119-124.

Ekdale, A.A., Lewis, D.W., 1991. Trace fossils and paleoenvironmental control of ichnofacies in a late Quaternary gravel and loess fan delta complex, New Zealand. Palaeogeography, Palaeoclimatology, Palaeoecology, 81: 253-279.

Fenton, C.L., Fenton, M.A., 1937. Archaeonassa, Cambrian snail trails and burrows. American Midland Naturalist, 18: 454-456.

Fillmore, D.L., Lucas, S.G., Simpson, E.L., 2011. The fish swimming trace Undichna from the Mississippian Mauch Chunk Formation, Eastern Pennsylvania. Ichnos, 8: 27-34.

Fischer-Ooster, C., 1858. Die fossilen Fucoiden der Schweizer Alpen, nebst Erörterungen über deren geologisches Alter. Huber, Bern.

Frey, R.W., Pemberton, S.G., 1984. Trace fossils facies models. In: Facies Models (ed. R.G. Walker): 189-207. Geoscience Canada, Reprint Series.

Frey, R.W., Curran, H.A., Pemberton, S.G., 1984. Tracemaking activities of crabs and their environmental significance: the ichnogenus Psilonichnus. Journal of Paleontology, 58: 333-350.

Fritsch, A., 1908. Problematica Silurica. Systême Silurien du Centre de la Bohême par Joachim Barrande. Suite Éditée-aux Frais du Barrande Fonds, Prague.

Fu, S., 1991. Funktion, Verhalten und Einteilung fucoider und lophocteniider Lebensspuren. CFS. Courier Forschungsinstitut Senckenberg, 135: 1-79.

Fürsich, F.T., Heinberg, C., 1983. Sedimentology, biostratinomy and palaeoecology of an Upper Jurassic offshore sand bar complex. Bulletin of the Geological Society of Denmark, 32: 67-95.

Geinitz, H.B., 1867. Über Dictyophyton? Liebeanum Gein. aus dem Culmschiefer vom Heersberge zwischen Gera und Weyda. Neues Jahrbuch für Mineralogie, Geologie und Paläontologie, 1867: 286-288.

Getty, P.R., Sproule, R., Stimson, M.R., Lyons, P.C., 2017. Invertebrate trace fossils from the Pennsylvanian Rhode Island Formation of Massachusetts, USA. Atlantic Geology, 53: 185-206.

Gibert, J.M. de, Buatois, L.A., Fregenal-Martínez, M.A., Mángano, M.G., Ortega, F., Poyato-Ariza, F.J., Wenz, S., 1999. The fish trace fossil Undichna from the Cretaceous of Spain. Palaeontology, 42: 409-427.

Głuszek, A,. 1998. Trace fossils from Late Carboniferous storm deposits, Upper Silesia Coal Basin, Poland. Acta Palaeontologica Polonica, 43: 517-546.

Goldring, R., Pollard, J.E., Radley, J.D., 2005. Trace fossils and pseudofossils from the Wealden strata (non-marine Lower Cretaceous) of southern England. Cretaceous Research, 26: 665-685.

Goldring, R., Pollard, J.E., Taylor, A.M., 1991. Anconichnus horizontalis; a pervasive ichnofabric-forming trace fossil in post-Paleozoic offshore siliciclastic facies. Palaios, 6: 250-263.

Gunia, T., 1968. On the fauna, stratigraphy and conditions of sedimentation of the Upper Devonian in the Świebodzice depres- sion (Middle Sudetes) (in Polish with English summary). Geologia Sudetica, 4: 1-220.

Gürich, G., 1909. Clymenienkalk von der Conradmühle in Polsnitz bei Freiburg in Schlesien. Abhandlungen der Preussischen Geologischen Landesanstalt, 30: 341-344.

Halamski, A.T., 2013. Frasnian Atrypida (Brachiopoda) from Silesia (Poland) and the age of the eo-Variscan collision in the Sudetes. Geodiversitas, 35: 289-308.

Hall, J., 1847. Paleontology of New York I. Geological Survey of New York, Albany. C. Van Benthuysen.

Han, Y., Pickerill, R.K., 1994. Taxonomic reassessment of Protovirgularia M'Coy 1850 with new examples from the Paleozoic of New Brunswick, eastern Canada. Ichnos, 3: 203-212.

Häntzchel, W., 1975. Trace fossils and problematica. In: Treatise on Invertebrate Paleontology. Part W. Miscellanea, Suppl. 1. (ed. C. Teichert). Geological Society of America and University of Kansas, Lawrence and Boulder.

Heer, O., 1877. Flora Fossilis Helvetiae. Die vorweltiliche Flora der Schweiz. Journal Wüster \& Co.

Heinberg, C. 1974. A dynamic model for a meniscus filled tunnel (Ancorichnus n. ichnogen.) from the Jurassic Pecten Sandstone of Milne Land, East Greenland. Rapport Grønlands Geologiske Undersøgelse, 62: 1-20.

Heinberg, C., Birkelund, T., 1984. Trace-fossil assemblages and basin evolution of the Vardekløft Formation (Middle Jurassic, central East Greenland). Journal of Paleontology, 58: 362-397.

Higgs, R., 1988. Fish trails in the Upper Carboniferous of southwest England. Palaeontology, 31: 255-272.

Hofmann, R., Goudemand, N., Wasmer, M., Bücher, H., Hautmann, M., 2011. New trace fossil evidence for an early recovery signal in the aftermath of the end-Permian mass extinction. Palaeogeography, Palaeoclimatology, Palaeoecology, 310: 216-226.

Hovikoski, J., Uchman, A., Alsen, P., Ineson, J., 2018. Ichnological and sedimentological characteristics of submarine fan-delta deposits in a half-graben, Lower Cretaceous Palnatokes Bjerg Formation, NE Greenland. Ichnos, 26: 28-57.

Hu, B., Wang, G., Goldring, R., 1998. Nereites (or Neonereites) from lower Jurassic lacustrine turbidites of Henan, central China. Ichnos, 6: 203-209.

Hubbard, S.M., MacEachern, J.A., Bann, K.L., 2012. Slopes. Developments in Sedimentology, 64: 607-642.

Ineson, J.R., 1987. Trace fossils from a submarine fan-slope Apron Complex in the Cretaceous of James Ross, Island, Antarctica. British Antarctic Survey Bulletin, 74: 1-16.

James, U.P., 1879. Description of new species of fossils and remarks on some others, from the Lower and Upper Silurian rocks of Ohio. The Paleontologist, 3: 17-24.

Joseph, J.K., Pate, I.S.J., Bhatt, N.Y., 2012. Trace fossil assemblages in mixed siliciclastic-carbonate sediments of the Kaladongar Formation (Middle Jurassic), Patcham Island, Kachchh, Western India. Journal of Geological Society of India, 80: 189-214.

Kaczorowski, M., Wojewoda, J., 2011. Neotectonic activity interpreter from a long water-tube tiltmeter record at the SRC geodynamic laboratory in Książ, Central Sudetes, SW Poland. Acta Geodynamica et Geomaterialia, 8: 1-13.

Keighley, D.G., Pickerill, R.K., 1994. The ichnogenus Beaconites and its distinction from Ancorichnus and Taenidium. Palaeontology, 37: 305-337.

Keighley, D.G., Pickerill, R.K., 1996. Small Cruziana, Rusophycus, and related ichnotaxa from eastern Canada: the nomenclatural debate and systematic ichnology. Ichnos, 4: 261-285.

Kim, J.-Y., 1994. A unique occurrence of Lockeia from the Yeongheung Formation (Middle Ordovician), Yeongwed, Korea. Ichnos, 3: 219-225.

Knaust, D., 2007. Invertebrate trace fossils and ichnodiversity in shallow-marine carbonates of the German Middle Triassic (Muschelkalk). SEPM Special Publication, 88: 221-238.

Knaust, D., 2010. Remarkably preserved benthic organisms and their traces from a Middle Triassic (Muschelkalk) mud flat. Lethaia, 43: 344-356. 
Knaust, D., 2019. The Fish Trail Undichna quadrisulcata isp. nov. from the Eocene of Spitsbergen. Ichnos, 26: 178-186.

Knaust, D., Minter, N.J., 2018. The fish swimming trace Undichna unisulca from the Silurian of Sweden: probably the oldest vertebrate locomotion trace fossil. Lethaia, 51: 469-472.

Książkiewicz, M., 1977. Trace fossils in the flysch of the Polish Carpathians. Palaeontologia Polonica, 36: 1-208.

Krawczyńska-Grocholska, H., 1973. Sporomorph assemblage in sandstone and siltstone samples from Chwaliszów in the Świebodzice Depression (Central Sudetes) (in Polish with English summary). Biuletyn Instytutu Geologicznego, 264: 211-222.

Krobicki, M., Uchman, A., 2003. Trace fossils Curvolithus from the Middle Jurassic Crinoidal Limestones of the Pieniny Klippen Belt (Carpathians, Poland). Geologica Carpathica, 54: 175-180.

Lehotský, T., Zapletal, J., 2007. Fosilní stopy $\mathrm{v}$ barokních břidličných podlahách vybraných olomouckých památek (In Czech). Zprávy Vlastivědného muzea v Olomouci, 289-291: $14-24$

Lima, J.H.D., Minter, N.J., Netto, R.G., 2017. Insights from functional morphology and neoichnology for determining tracemakers: a case study of the reconstruction of an ancient glacial arthropod-dominated fauna. Lethaia, 50: 576-590.

Lockley, M.G., Rindsberg, A.K., Zeiler, R.M., 1987. The paleoenvironmental significance of the nearshore Curvolithus ichnofacies. Palaios, 2: 255-262.

Löwemark, L., Schönfeld, J., Werner, F., Schäfer, P., 2004. Trace fossils as a paleoceanographic tool: evidence from late Quaternary sediments of the southwestern Iberian margin. Marine Geology, 204: 27-41.

Lucas, S.G., Lerner, A.J., Bruner, M., Shipman, P., 2004. Middle Pennsylvanian ichnofauna from Eastern Oklahoma, USA Ichnos, 11: 45-55.

Lucas, S.G., Krainer, K., Voigt, S., 2013. The Lower Permian Yeso Group in Central New Mexico. New Mexico Museum of Natural History and Science, Bulletin, 59: 181-200.

Mángano, M.G., Buatois, L.A., Guinea, F.M., 2005. Ichnology of the Alfarcito Member (Santa Rosita Formation) of northwestern Argentina: animal-substrate interactions in a Lower Paleozoic wave-dominated shallow sea. Ameghiniana, 42: 641-668.

Mángano, M.G., Buatois, L.A., Hofmann, R., Elicki, O., Shinaq, R., 2013. Exploring the aftermath of the Cambrian explosion: the evolutionary significance of marginal- to shallow-marine ichnofaunas of Jordan. Palaeogeography, Palaeoclimatology, Palaeoecology, 374: 1-15.

Mángano, M.G., Buatois, L.A., Maples, C.G., West, R.R., 2000. A new ichnospecies of Nereites from Carboniferous tidal-flat facies of Eastern Kansas, USA: implications for the NereitesNeonereites debate. Journal of Paleontology, 74: 149-157.

Mángano, M.G., Buatois, L.A., Rindsberg, A.K., 2002a. Carboniferous Psammichnites: systematic re-evaluation, taphonomy and autecology. Ichnos, 9: 1-22.

Mángano, M.G., Buatois, L.A., West, R.R., Maples, C.G., 2002b Ichnology of a Pennsylvanian Equatorial Tidal Flat: the Stul Shale Member at Waverly, Eastern Kansas. Kansas Geological Survey Bulletin 245: 1-133.

Maples, C.G., Suttner, L.J., 1990. Trace fossils and marine-nonmarine cyclicity in the Fountain Formation (Pennsylvanian: Morrowan/Atokan) near Manitou Springs, Colorado. Journal of Paleontology, 64: 859-880.

Marriott, S.B., Hillier, R.D., Morrissey, L.B., 2013. Enigmatic sedimentary structures in the Lower Old Red Sandstone, south Wales, UK: possible microbial influence on surface processes and early terrestrial food webs. Geological Magazine, 150 396-411.

Mastalerz, K., 1987. Sedymentacja w basenie śródsudeckim na przełomie dolnego i górnego karbonu (in Polish). In: Przewodnik LVIII Zjazdu Polskiego Towarzystwa Geologicznego Wałbrzych 17-19 września 1987 (eds. Z. Baranowski, A. Grocholski, J. Malinowski, J. Oberc and S. Porębski): 134-145. AGH, Kraków.

Mastalerz, K., 1995. Deposits of high-density turbidity currents on fan-delta slopes: an example from the upper Visean Szczawno
Formation, Intrasudetic Basin, Poland. Sedimentary Geology, 98: 121-146.

McCoy, F., 1850. On some genera and species of Silurian Radiata in the collection of the University of Cambridge. Annals and Magazine of Natural History, Ser. 2, 6: 270-290.

Mcllroy, D., 2008. Ichnological analysis: the common ground between ichnofacies workers and ichnofabric analysts. Palaeogeography, Palaeoclimatology, Palaeoecology, 270: 332-338.

Melchor, R.N., Genise, J.F., Buatois, L.A., Umazano, A.M., 2012 Fluvial environments. Developments in Sedimentology, 64: 329-378.

Mikuláš, R., 2006. Ichnofabric and substrate consistency in Upper Turonian carbonates of the Bohemian Cretaceous Basin (Czech Republic). Geologica Carpathica, 57: 79-90.

Mikuláš, R., Lehotský, T., Bábek, O., 2002. Lower Carboniferous ichnofabrics of the Culm facies: a case of study of the Moravice Formation (Moravia and Silesia, Czech Republic). Geologica Carpathica, 53: 141-148.

Mikuláš, R., Lehotský, T., Bábek, O., 2004. Trace fossils of the Moravice Formation from the southern Nízký Jesenik Mts. (Lower Carboniferous, Culm facies; Moravia, Czech Republic). Bulletin of Geosciences, 79: 81-98

Mikuláš, R., Meškis, S., Ivanov, A., Lukševičs, E., Zupinš, I., Stinkulis, İ., 2013. A rich ichnofossil assemblage from the Frasnian (Upper Devonian) deposits at Andoma Hill, Onega Lake, Russia. Bulletin of Geosciences, 88: 389-400.

Minter, N.J., Braddy, S.J., 2006. The fish and amphibian swimming traces Undichna and Lunichnium, with examples from the Lower Permian of New Mexico, USA. Palaeontology, 49: 1123-1142.

Minter, N.J., Braddy, S.J., 2009. Ichnology of an Early Permian Intertidal Flat: The Robledo Mountains Formation of Southern New Mexico, USA. Special Paper in Palaeontology, 82: 5-107.

Minter, N.J., Buatois, L.A, Mángano, M.G., 2016. The conceptual and methodological tools of ichnology. In: The Trace-Fossil Record of Major Evolutionary Events, 1. Precambrian and Paleozoic (eds. M.G. Mángano and L.A. Buatois): 1-26. Springer.

Murchison, R. I., 1839. The Silurian System. John Murray, London.

Muszer, J., 2013. Skamieniałości śladowe z formacji ze Szczawna okolic Wałbrzycha (Sudety Środkowe) - wstepne wyniki badań (in Polish). In: Aktualizm i antyaktualizm w paleontologii (eds. M. Kędzierski and B. Kołodziej). XXII Konferencja Naukowa Sekcji Paleontologicznej Polskiego Towarzystwa Geologicznego, Tyniec, 27-30 września 2013 r.: 34-35. Materiały Konferencyjne, Polskie Towarzystwo Geologiczne, Kraków.

Muszer, J., 2019. Trace fossils from the Witoszów region - preliminary results (in Polish). In: From Precambrian to Holocene biodiversity changes recorded in the rocks (eds. J. Muszer, A Chrząstek and R. Niedźwiedzki). XXIV Konferencja Naukowa Sekcji Paleontologicznej PTG, Wrocław, Długopole Górne 11-14 września 2019: 61-62.

Muszer, J., 2020. Trace fossils from the Mississippian of the Piaskowa Góra section (the Intra-Sudetic Basin, SW Poland). Annales Societatis Geologorum Poloniae, 90: in press, doi: https://doi.org/10.14241/asgp.2020.06

Muszer, J., Haydukiewicz, J., 2009. Occurrence of the trace fossil Zoophycos from the Upper Viséan Paprotnia Beds of the Bardo Structural Unit (Sudetes, SW Poland). Geologia Sudetica, 41 $57-66$

Muszer, J., Haydukiewicz, J., 2010. First Paleozoic Zoophycos trace fossils from the Sudetes (the Bardo Unit). Geological Quarterly, 54 (3): 381-384.

Muszer, J., Uglik, M., 2013. Palaeoenvironmental reconstructions of the Upper Visean Paprotnia Beds (Bardo Unit, Polish Sudetes) using ichnological and palaeontological data. Geological Quarterly, 57 (3): 365-384

Muszer, J., Górecka-Nowak, A., Kryza, R., August, C., 2016. New data on biostratigraphy and chronostratigraphy of the Carboniferous sediments in Sudetes (in Polish). In: XXIII Konferencja Naukowa Sekcji Paleontologicznej Polskiego Towarzystwa Geologicznego, 21-23 września 2016 Poznań, Abstrakty (eds. K. Pawłowska and D. Pawłowski): 73-74. 
Nara, M., Ikari, Y., 2011. Deep-sea bivalvian highways: An ethological interpretation of branched Protovirgularia of the Palaeogene Muroto-Hanto Group, southwestern Japan. Palaeogeography, Palaeoclimatology, Palaeoecology, 305: 250-255.

Naruse, H., Nifuku, K., 2008. Three dimensional morphology of the ichnofossil Phycosiphon incertum and its implication for paleoslope inclination. Palaios, 23: 270-279.

Nemec, W., Porębski, S.J., Steel, R.J., 1980. Texture and structure of resedimented conglomerates: examples from Książ Formation (Famennian-Tournaisian), southwestern Poland. Sedimentology, 27: 519-538.

Nemec, W., Porębski, S.J., Teisseyre, A.K., 1982. Explanatory notes to the lithotectonic molasses profile of the Intra-Sudetic Basin, Polish Part (Sudety Mts., Carboniferous-Permian) (Comment to Annex 23). Veröffentlichungen des Zentralinstituts für Physik der Erde. Akademie der Wissenschaften der DDR, Potsdam, 66: 267-278.

Netto, R.G., Brenner, J.S., Buatois, L.A., Uchman, A., Mángano, M.G., Ridge, J.C., Kazakauskas, V., Gaigalas, A., 2012a. Glacial environments. Developments in Sedimentology, 64: 299-327.

Netto, R.G., Tognoli, F.M.W., Gandini, R., Lima, J.H.D., de Gibert, J.M., 2012b. Ichnology of the Phanerozoic deposits of southern Brazil: synthetic review. Monografías da Sociedade Brasileira de Paleontología, 2: 37-68.

Noffke, N., Gerdes, G., Klenke, T., Krumbein, W.E., 2001. Microbially induced sedimentary structures - a new category within the classification of primary sedimentary structures. Journal of Sedimentary Research, 71: 649-656.

Noffke, N., Beukes, N., Gutzmer, J., Haze, R., 2006. Spatial and temporal distribution of microbially induced sedimentary structures: A case study from siliciclastic storm deposits of the $2.9 \mathrm{Ga}$ Witwatersrand Supergroup, South Africa. Precambrian Research, 146: 35-44.

Olivero, E.B., Medina, F.A., López, C.M.I., 2009. The stratigraphy of Cretaceous mudstones in the eastern Fuegian Andes: new data from body and trace fossils. Revista de la Asociación Geológica Argentina, 64: 60-69.

Olivero, E.B., Lopez, M.I., Malumian, N., Torres Carbonell, P.J., 2010. Eocene graphoglyptids from shallow-marine, high energy, organic-rich, and bioturbated turbidites, Fuegian Andes, Argentina. Acta Geologica Polonica, 60: 77-91.

Orr, P.J., 2001. Colonization of the deep-marine environment during the early Phanerozoic: the ichnofaunal record. Geological Journal, 36: 265-278.

Orr, P.J., Benton, M.J., Trewin, N.H., 1996. Deep marine trace fossils assemblages from the Lower Carboniferous of Menorca, Balearic Islands, western Mediterranean. Geological Journal, 31: 235-258

Pazos, P.J., 2002. Palaeoenvironmental framework of the glacial-postglacial transition (Late Paleozoic) in the Paganzo-Calingasta Basin (Southern South America) and the Great Karoo-Kalahari Basin (Southern Africa): ichnological implications. Gondwana Research, 5: 619-640.

Pazos, P.J., di Pasquo M., Amenabar C.R., 2007. Trace fossils of the glacial to postglacial transition in the El Imperial Formation (Upper Carboniferous) San Rafael Basin, Argentina. SEPM Special Publication, 88: 137-147.

Pazos, P.J., Gutiérrez, C., Fernández, D.E., Heredia, A.M., Comerio, M., 2015a. The unusual record of Nereites, wrinkle marks and undermat mining trace fossils from the late Silurian-earliest Devonian of central-western margin of Gondwana (Argentina). Palaeogeography, Palaeoclimatology, Palaeoecology, 439: 4-16.

Pazos, P.J., Heredia, A.M., Fernández, D.E., Gutiérrez, C., Comeria, M., 2015b. The ichnogenus Dictyodora from late Silurian deposits of central-western Argentina: ichnotaxonomy, ethology and ichnostratigraphical perspectives from Gondwana. Palaeogeography, Palaeoclimatology, Palaeoecology, 439: $27-37$
Pawlik, D., 1939. Zur Stratigraphie des südlichen Freiburger Oberdevongebietes (Schlesien). Neues Jahrbuch für Mineralogie, Geologie und Paläontologie. Beilage-Bände 81: 23-60.

Pek, I., Zapletal, J., 1990. The importance of ichnology in geologic studies of the eastern Bohemian Massif (Lower Carboniferous), Czechoslovakia. Ichnos, 1: 147-149.

Pemberton, S.G., Frey, R.W., 1982. Trace fossil nomenclature and the Planolites-Palaeophycus dilemma. Journal of Paleontology, 56: 843-881.

Pemberton, S.G., MacEachern, J.A., Dashtgard, S.E., Bann, K.L., Gingras, M.K., Zonneveld, J.-P., 2012. Shorefaces. Developments in Sedimentology, 64: 563-603.

Pluta, K., Górecka-Nowak, A., 2018. Miospore evidence for the Carboniferous age of rocks from the Świebodzice Unit (Sudetes, SW Poland). Geological Quarterly, 62 (1): 120-133.

Porębski, S.J., 1981. Świebodzice succession (Upper Devonian-lowest Carboniferous): a prograding mass flow dominated fan-delta complex (in Polish with English summary). Geologia Sudetica, 16: 101-192.

Porębski, S.J., 1987. Środowisko depozycyjne i wpływ tektoniki na sedymentację dewonu-karbonu w depresji Świebodzic (in Polish). In: Przewodnik LVIII Zjazdu Polskiego Towarzystwa Geologicznego Wałbrzych 17-19 września 1987 (eds. Z. Baranowski, A. Grocholski, J. Malinowski, J. Oberc and S. Porębski): 114-130. AGH, Kraków.

Porębski, S.J., 1990. Onset of coarse clastic sedimentation in the Variscan realm of the Sudetes (SW Poland): an example from the Upper Devonian-Lower Carboniferous Świebodzice succession. Neues Jahrbuch für Geologie und Paläontologie Abhandlungen, 179: 259-274.

Radley, J.D., Barker, M.J., Munt, M.C., 1998. Bivalve trace fossils (Lockeia) from the Barnes High Sandstone (Wealden Group, Lower Cretaceous) of the Wessex Sub-basin, southern England. Cretaceous Research, 19: 505-509.

Richter, R., 1850. An der Thüringischen Grauwacke. Zeitschrift der Deutschen Geologischen Gesellschaft, 2: 198-206.

Rodríguez-Tovar, F.J., Stachacz, M., Uchman, A., Reolid, M., 2014. Lower/Middle Ordovician (Arenigian) shallow-marine trace fossils of the Pochico Formation, southern Spain: palaeoenvironmental and palaeogeographic implications at the Gondwanan and peri-Gondwanan realm. Journal of Iberian Geology, 40: 539-555.

Rodríguez-Tovar, F.J., Uchman, A., Payros, A., Orue-Etxebarria, X., Apellaniz, E., Molina, E., 2010. Sea level dynamics and palaeoecological factors affecting trace fossil distribution in Eocene turbiditic deposits (Gorrondatxe section, N Spain). Palaeogeography, Palaeoclimatology, Palaeoecology, 285: 50-65.

Roemer, F., 1870. Geologie von Oberschlesien. Eine Erläuterung zu der im Auftrage des Königl. Preuss. Handels- Ministeriums von dem Verfasser bearbeiteten geologischen Karte von Oberschlesien in 12 Sektionen, Atlas von 50 Tafeln mit Abbildungen von Versteinerungen. Breslau.

Ronchi, A., Santi, G., Marchetti, L., Bernardi, M., Gianolla, R., 2018. First report of swimming trace fossils of fish from the Upper Permian and Lower Triassic of the Dolomites (Italy). Annales Societatis Geologorum Poloniae, 88: 111-125.

Różkowska, M., 1962. The Devonian coral limestones by the Daisy Lake of Mokrzeszów (in Polish with English summary). Biuletyn Informacyjny Polskiego Towarzystwa Miłośników Nauk o Ziemi: 3-5.

Ruchholz, K., 1967. Zur Ichnologie und Facies des Devons und Unterkarbons im Harz. Geologie, 16: 503-527.

Sadlok, G., 2008. Ślad Diplopodichnus biformis Brady, 1947 ze środkowego triasu (Jaworzno, Górny Śląsk) - potencjalny wskaźnik warunków subaeralnych? (in Polish). Przegląd Geologiczny, 56: 964-966.

Sarkar, S., Banerjee, S., 2019. Microbial mat structures formed within siliciclastics. In: A synthesis of depositional sequence of the Proterozoic Vindhyan Supergroup in Son Valley. A Field Guide (eds S. Sarkar and S. Banerjee): 165-183. Springer. 
Sarkar, S., Ghosh, S. K., Chakraborty, C., 2009. Ichnology of a Late Palaeozoic ice-marginal shallow marine succession: Talchir Formation, Satpura Gondwana basin, central India Palaeogeography, Palaeoclimatology, Palaeoecology, 283 28-45.

Savrda, C.E., Krawinkel, H., McCarthy, F.M.G., McHugh, C.M.G. Olson, H.C., Mountain, G., 2001. Ichnofabrics of a Pleistocene slope succession, New Jersey margin: relations to climate and sea-level dynamics. Palaeogeography, Palaeoclimatology, Palaeoecology, 171: 41-61.

Schatz, E.R., Mángano, M.G., Buatois, L.A., Limarino, C.O. 2011. Life in the Late Paleozoic Ice Age: trace fossils from glacially influenced deposits in a Late Carboniferous fjord of western Argentina. Journal of Paleontology, 85: 502-518.

Seilacher, A., 1967. Bathymetry of trace fossils. Marine Geology, 5 413-428.

Seilacher, A., 1974. Flysch trace fossils: evolution of behavioural diversity in the deep-sea. Neues Jahrbuch für Geologie und Paläontologie Monatshefte (4): 233-245.

Seilacher, A., 1977. Pattern analysis of Paleodictyon and related trace fossils. Geological Journal, Special Issues, 9: 289-334

Seilacher, A., 1978. Use of trace fossils for recognizing depositional environments. SEPM Short Course Notes, 5: 167-181.

Seilacher, A., 1986. Evolution of behaviour as expressed in marine trace fossils. In: Evolution of Animal Behavior: Paleontological and Field Approaches (eds. M.H. Nitecki and J.A. Kitchell): 62-87. Oxford University Press, New York.

Seilacher, A., 1997. Fossil Art. Drumheller, Alberta, The Royal Tyrrell Museum of Palaeontology.

Seilacher, A., 2007. Trace Fossil Analysis. Springer-Verlag, Berlin, Heidelberg.

Seilacher, A., Meischner, D., $1965 . \quad$ Facies-Analyse im Paläozoikum des Oslo-Gebietes. Geologische Rundschau, 54: 596-619.

Simon, T., Hagdorn, H., Hagdorn, M.K., Seilacher, S., 2003 Swimming trace of a coelacanth fish from the Lower Keuper of south-west Germany. Palaeontology, 46: 911-926.

Soler-Gijón, R., Moratalla, J.J., 2001. Fish and tetrapod trace fossil from the Upper Carboniferous of Puertollano, Spain. Palaeogeography, Palaeoclimatology, Palaeoecology, 171: 1-28.

Stepanek, J., Geyer, G., 1989. Spurenfosilien aus dem Kulm (Unterkarbon) des Frankenwaldes. Beringeria, 1: 1-55.

Sternberg, G.K. von, 1833. Versuch einer geognostisch botanischen Darstellung der Flora der Vorwelt. IV Heft. V. C.E. Brenck, Regensburg.

Teisseyre, A.K., 1968a. The Lower Carboniferous of the Intra-Sudetic Basin: a study in sedimentary, petrography and basin analysis (in Polish with English summary). Geologia Sudetica, 4: 221-298.

Teisseyre, H., 1948. Sprawozdanie z prac geologicznych wykonanych w Sudetach w r. 1947 (in Polish). Badania fizjograficzne nad Polską Zachodnią, 1: 6-47.

Teisseyre, H., 1952. Geological structure of the northern region of Wałbrzych (in Polish with English summary). Biuletyn Instytutu Geologicznego, 62: 5-58.

Teisseyre, H., 1956a. On Upper Devonian sedimentation in Pogorzała and Witoszów (Middle Sudeten, Poland) (in Polish with English summary). Acta Geologica Polonica, 6: 227-251.

Teisseyre, H., 1956b. Świebodzice Depression as a geological unit (in Polish with English summary). Biuletyn Instytutu Geologicznego, 106: 5-36.

Teisseyre, H., 1968b. Stratigraphy and tectonics of the Świebodzice depression. Biuletyn Instytutu Geologicznego, 222: $71-106$

Torell, O.M., 1870. Petrificata Suecana Formationis Cambricae. Acta Universitets Lundensis, Lunds Universit Årsskrift, 2: 1-14.

Trewin, N.H., 2000. The ichnogenus Undichna, with examples from the Permian of the Falkland Islands. Palaeontology, 43: 979-997.

Tyszka, J., 1994. Paleoenvironmental implications from ichnological and microfaunal analyses of Bajocian Spotty Car- bonates, Pieniny Klippen Belt, Polish Carpathians. Palaios, 9: $175-187$.

Uchman, A., 1995. Taxonomy and palaeoecology of flysch trace fossils: The Marnoso-arenacea Formation and associated facies (Miocene, Northern Apennines, Italy). Beringeria, 15: $1-115$

Uchman, A., 1998. Taxonomy and ethology of flysch trace fossils: A revision of the Marian Ksiazżkiewicz collection and studies of complementary material. Annales Societatis Geologorum Poloniae, 68: 105-218.

Uchman, A., 2003. Trends in diversity, frequency and complexity of graphoglyptid trace fossils: evolutionary and palaeoenvironmental aspects. Palaeogeography, Palaeoclimatology, Palaeoecology, 192: 123-142.

Uchman, A., 2004. Phanerozoic history of deep-sea trace fossils. Geological Society Special Publications, 228: 125-140.

Uchman, A., 2007a. Deep-sea ichnology: development of major concepts. In: Trace Fossils: Concepts, Problems, Prospects (ed. W. III Miller): 248-267. Elsevier, Italy.

Uchman, A., 2007b. Deep-sea trace fossils from the mixed carbonate-siliciclastic flysch of the Monte Antola Formation (Late Campanian-Maastrichtian), North Apennines, Italy. Cretaceous Research, 28: 980-1004.

Uchman, A., Gaździcki, A., 2006. New trace fossils from the La Meseta Formation (Eocene) of Seymour Island, Antarctica. Polish Polar Research, 27: 153-170.

Uchman, A., Wetzel, A., 2011. Deep-sea ichnology: the relationships between depositional environment and endobenthic organisms. Developments in Sedimentology, 63: 517-556.

Uchman, A., Wetzel, A., 1999. An aberrant, helicoidal trace fossi Chondrites Sternberg. Palaeogeography, Palaeoclimatolology, Palaeoecology, 146: 165-169.

Uchman, A., Wetzel, A., 2012. Deep-sea fans. Developments in Sedimentology, 64: 643-671.

Uchman, A., Mikuláš, R., Houša, V., 2003. The trace fossil Chondrites in uppermost Jurassic-Lower Cretaceous deep cavity fills from the Western Carpathians (Czech Republic). Geologica Carpathica, 54: 181-187.

Uchman, A., Janbu, N.E., Nemec, W., 2004. Trace fossils in the Cretaceous-Eocene flysch of the Sinop-Boyabat Basin, Centra Pontides, Turkey. Annales Societatis Geologorum Poloniae, 74 197-235.

Uchman, A., Hu, B., Wang, Y., Song, H., 2011. The trace fossi Diplopodichnus from the Lower Jurassic lacustrine sediments of Central China and the isopod Armadillidium vulgare (Pillbug) lebensspuren as its Recent analogue. Ichnos, 18: 147-155.

Uchman, A., Caruso, C., Sonnino, M., 2012. Taxonomic review of Chondrites affinis (Sternberg, 1833) from Cretaceous-Neogene offshore-deep-sea Tethyan sediments and recommendation for its further use. Rivista Italiana di Paleontologia e Stratigrafia, 118: 313-324

Vialov, O.S., 1962. Problematica of the Beacon Sandstone at Beacon Haights, West Antarctica. New Zealand Journal of Geology and Geophysics, 5: 718-732.

Vieira de Luca, P.H., Basilici, G., 2013. A prodeltaic system controlled by hyperpycnal flows and storm waves: reinterpretation of the Punta Negra Formation (Lower-Middle Devonian, Argentine Precordillera). Brazilian Journal of Geology, 43: 673-694.

Vodrážková, S., Vodrážka, R., Munnecke, A., Franců, J., Al-Bassam, K., Halodová, P., Tonarová, P., 2019. Microbially induced wrinkle structures in Middle Devonian siliciclastics from the Prague Basin, Czech Republic. Lethaia, 52: 149-164.

Webby, B.D., 1970. Late Precambrian trace fossils from New South Wales. Lethaia, 3: 79-109

Weiss, E., 1884. Vorlegung des Dictyophytum liebeanum Gein. aus der Gegend von Gera. Gesellschaft Naturforschender Freunde Berlin, Sitzungsberichte, 17

Wetzel, A., 1984. Bioturbation in deep-sea fine-grained sediments: influence of sediment texture, turbidite frequency and rates of environmental change. Geological Society Special Publications, 15: 595-608. 
Wetzel, A., 1991. Ecologic interpretation of deep-sea trace fossil communities. Palaeogeography, Palaeoclimatology, Palaeoecology, 85: 47-69.

Wetzel, A., 2002. Modern Nereites in the South China Sea-ecological association with redox conditions in the sediment. Palaios, 17: 507-515.

Wetzel, A., 2008. Recent bioturbation in the deep South China Sea: a uniformitarian ichnologic approach. Palaios, 23: 601-615.

Wetzel, A., 2010. Deep-sea ichnology: Observations in modern sediments to interpret fossil counterparts. Acta Geologica Polonica, 60: 125-138.

Wetzel, A., Bromley, R.G., 1994. Phycosiphon incertum revisited: Anconichnus horizontalis is its junior subjective synonym. Journal of Paleontology, 68: 1396-1402.

Wetzel, A., Uchman, A., 2001. Sequential colonization of muddy turbidites in the Eocene Beloveža Formation, Carpathians, Poland. Palaeogeography, Palaeoclimatology, Palaeoecology, 168: 171-186.

Wojewoda, J., 2014. Świebodzice Unit revisited - kinematic, structural and facial evolution till now. In: Abstracts of 15th Czech-Polish Workshop on Recent Geodynamics of the Sudetes and the Adjacent Areas, Karlov pod Pradědem, November 5-8, 2014 (eds. J. Stemberk and P. Štěpančíková): 63-64.

Wojewoda, J., 2016a. Basen świebodzki - granice, architektura osadów i ewolucja strukturalna (in Polish). In: VI Polska Konferencja Sedymentologiczna POKOS 6 - Granice Sedymentologii 28.06-01.07.2016, Chęciny-Rzepka (eds. D. Olszewska-Nejbert, A. Filipek, M. Bąbel and A. Wysocka): 142-144.

Wojewoda, J., 2016b. About the need to develop the second edition of the detailed geological map of the Sudetes at the scale of 1:25 000 - examples of a revision of the geological pattern using the LIDAR Digital Elevation Models (in Polish with English summary). Przegląd Geologiczny, 64: 597-603.
Yochelson, E.L., Fedonkin, M.A., 1997. The type specimens (Middle Cambrian) of the trace fossil Archaeonassa Fenton \& Fenton. Canadian Journal of Earth Sciences, 34: 1210-1219.

Young, F.G., 1972. Early Cambrian and older trace fossils from the southern Cordillera of Canada. Canadian Journal of Earth Sciences, 9: 1-17.

Zapletal, J., Pek, I., 1987. Trace fossil assemblages and their occurrence in lower Carboniferous of the Nízký Jesenik Mts. Acta Universitatis Palackianae Olomuncensis, GeographicaGeologica, 26: 47-64.

Zhang, G., Buatois, L.A., Mángano, M.G., Aceñolaza, F.G., 1998. Sedimentary facies and environmental ichnology of a Permian playa-lake complex in western Argentina. Palaeogeography, Palaeoclimatology Palaeoecology, 138: 221-243.

Zhu, M., 1997. Precambrian-Cambrian trace fossils from eastern Yunnan, China: implications for Cambrian explosion. Bulletin of National Museum of Natural Science, 10: 275-312.

Zimmermann, F., 1936. Das Alter der Gneiskonglomerate des Fürstensteiner Kulms. Jahrbuch der Preussischen Geologischen Landesanstalt, 56: 205-207.

Zobel, J., Carnall, R., 1831. Geognostische Beschreibung von einem Theile des Nieder-Schlesischen, Glätzischen und Böhmischen Gebirges. Archiv für Mineralogie, Geognosie, Bergbau und Hüttenkunde, 4: 3-173.

Żakowa, H., 1958. Biostratigraphy of the Lower Carboniferous marine deposits of the area of Wałbrzych Miasto (Lower Silesia) (in Polish with English summary). Prace Instytutu Geologicznego, 19.

Żakowa, H., 1960. The upper Visean from Konradów near Wałbrzych (Lower Silesia) (in Polish with English summary). Kwartalnik Geologiczny, 4 (2): 331-355.

Żelaźniewicz, A., Aleksandrowski, P., Buła, Z., Karnkowski, P.H., Konon, A., Oszczypko, N., Ślączka, A., Żaba, J., Żytko, K., 2011. Regionalizacja tektoniczna Polski (in Polish). Komitet Nauk Geologicznych PAN. 